\title{
Which are the factors that may explain the differences in water and energy consumptions in urban and rural environments?
}

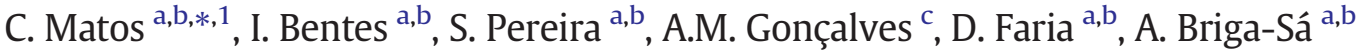 \\ ${ }^{a}$ ECT-School of Science and Technology, University of Trás-os-Montes e Alto Douro UTAD, Quinta de Prados, 5000-801 Vila Real, Portugal \\ ${ }^{\mathrm{b}}$ C-MADE-Centre of Materials and Building Technologies, University of Beira Interior, 6201-001 Covilhã, Portugal \\ c Department of Mathematics and Applications, CMAT-Centre of Mathematics, University of Minho, Guimarães, Portugal
}

\section{H I G H L I G H T S}

- Factors that may support differences in water and energy consumptions in rural and urban areas

- Where found significant differences between rural and urban environments

- Descriptive data analysis and statistical inference (ST) are performed.

- Started with 80 variables after ST only 42 remained as differentiating factors of environments.

\section{A R T I C L E I N F O}

\section{Article history:}

Received 26 April 2018

Received in revised form 5 June 2018

Accepted 6 June 2018

Available online 12 June 2018

Editor: D. Barcelo

\section{Keywords:}

Water and energy consumptions

Rural and urban environments

Survey

Statistical data analysis

Differentiating factors

\section{G R A P H I C A L A B S T R A C T}

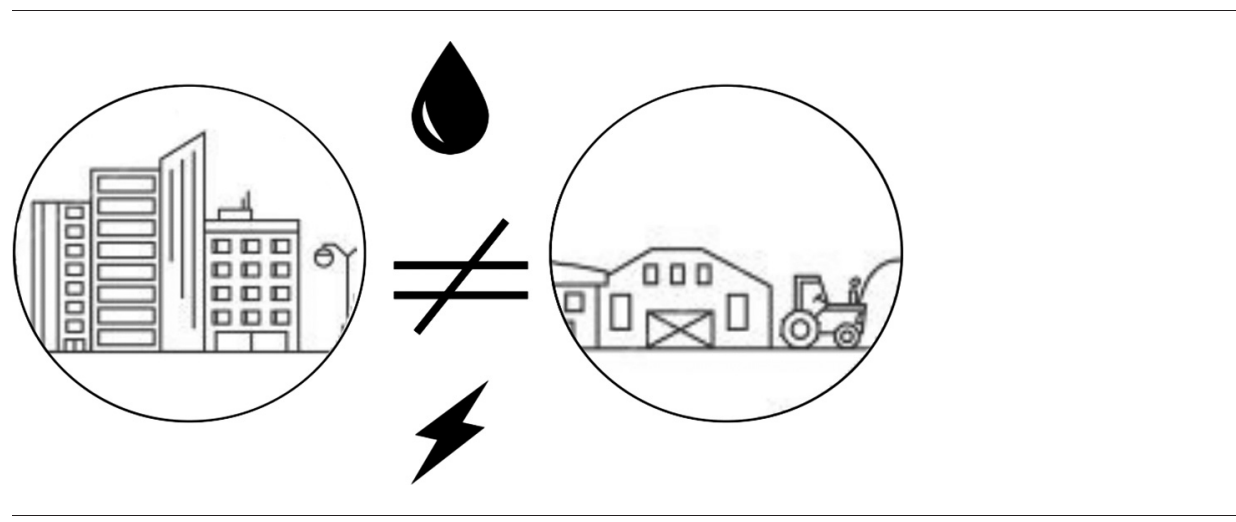

\begin{abstract}
A B S T R A C T
Rural and urban environments present significant differences between water and energy consumptions. It is important to know, in detail, which factors related to the consumption of these two resources are different in both environments, once that will be those important to manage and discuss in order to improve its use efficiency and sustainability. This research work involves a survey whose aim is to find the factors that in rural and urban environments may justify the differences found in water and energy consumptions. Besides the collection of water and energy consumption data, this survey analyzed 80 variables (socio-demographic, economic, household characterization, among others), that were chosen among the bibliography as possible factors that should influence water and energy consumptions. After the survey application in rural and urban areas and the data statistical treatment, 42 variables remained as truly differentiating factors of rural and urban environments and so as possible determinants of water and energy consumptions. In order to achieve these objectives, a descriptive data analysis and statistical inference (Mann-Whitney-Wilcoxon test and the Chi-square test of homogeneity) were performed.

All the 42 differentiating variables that result from this study may be able to justify these differences, however this will not be presented in the paper and it is reserved for future work.
\end{abstract}

(C) 2018 Elsevier B.V. All rights reserved.

\footnotetext{
* Corresponding author at: University of Trás-os-Montes e Alto Douro (UTAD), Escola de Ciências e Tecnologia, 5000-801 Vila Real, Portugal.

E-mail address: crismato@utad.pt (C. Matos).

${ }^{1}$ www.utad.pt.
}

\section{Introduction}

Over the last twenty years, the European Commission has taken policy initiatives using the definitions of urban/rural spaces to affect resources. These definitions are mainly based on territorial characteristics. Some 
efforts have been made in order to distinguish urban areas from rural ones. For example, at the European level (Jonard et al., 2009):

- "45 minutes travel time to reach an urban centre with at least 50000 inhabitants" has been selected to classify a commune as "remote" or "close to an urban centre";

- A commune is classified as an "open space" commune if at least $75 \%$ of its area is covered by forest, agricultural or natural areas. Otherwise, the commune is characterized as "closed space".

In 1994, the Organisation for Economic Co-operation and Development (OECD) established a simple territorial structure that identifies types of regions based on population density applied at two hierarchical levels (the local community level and the regional level). Given that at the European level there is no commonly-agreed definition of rural area, the OECD typology is considered as an easy and acceptable approach for identifying rural areas (Jonard et al., 2009).

While rural areas may develop randomly according to the natural ecosystem in a given region, urban spaces are normally properly planned, and built up according to a process called urbanization, in conformity with the criteria settled in a Municipal Master Plan (PDM). Sometimes, it is very difficult to delineate the frontiers between rural and urban areas, and the typology developed by the OCDE (2005) was operationalized for the European-level territory at the regional level (NUTS 3 or NUTS 2) using three categories of space: "predominantly urban areas", "median urban areas" and "predominantly rural areas." In Portugal, according to the National Statistical Institute (INE, 2015), an urban space is a statistical subsection that includes one of the following requirements:

1 - It has to be typified as "urban soil", according to the PDM criteria;

2 - It has to comprise a section with a population density of $>500$ inhabitants per $\mathrm{km}^{2}$;

3 - It includes a place with a resident population of 5000 inhabitants or more.

A "predominantly rural area" is a statistical subsection typified as "non-urban land", according to the PDM criteria, and includes all of the following requirements:

1 - It was not previously included in the category of urban or semiurban space;

2 - It has a population density equal to/or $<100$ inhabitants per $\mathrm{km}^{2}$;

3 - It does not include a place with a resident population of 2000 in-

habitants or more.

"Urban soil" is defined as land with recognized aptitude for the process of urbanization and construction, constituting its entire urban perimeter. The OCDE typology is exclusively based on population densities and is highly sensitive to the size of the geographical units. However, this may differ from country to country. In China, density requirement for an urban area is about 1500 persons $/ \mathrm{km}^{2}$. Two urban areas with less than two kilometres between them are considered an urban sector (Martin, 1992). In Australia, urban cities must include at least 1000 residents, with a population density of 200 persons $/ \mathrm{km}^{2}$, while in Canada an urban area is defined by a density of 400 persons/ $\mathrm{km}^{2}$ (ABS, 2017).

Unlike rural areas, urban settlements are defined by their progressive public facilities and high levels of attendance. Public facilities include water and energy services and it would be normal to expect that some differentiator factors of urban and rural environments will influence water and energy consumption. Urban customers usually pump, heat, wash and cook more than agricultural rural consumers that pump more water to irrigate fields and, consequently, it is expected that energy consumption in the two environments diverge widely
(Arpke and Hutzler, 2006; Cheng, 2002). Rural water and energy demand management has been mainly focused on meeting the agricultural needs and policy-makers ignore the residential use.

Water used in the dwellings is of high quality and therefore a very expensive water. In addition to this situation, the consumption of water implies consumption of energy. Inside the dwellings, energy consumptions is also related to hot water consumption, and has very high costs and may have very serious consequences both in resource depletion and in pollution.

Knowledge of the factors that influence water consumption is very important to define strategies for its use and thus reduce costs, preserve the environment and public health. The different living habits of rural and urban populations, the different economic activities they develop and the type of housing and the surrounding garden or cultivated area, lead one to admit that the way they use water is also different. Thus, strategies for the use and reuse of water for rural and urban environments can be substantially different. In order to define water use strategies, that minimize consumption in the public network, that increase reuse, that reduce waste and that reduce energy associated consumption with water consumption, it is necessary to act in an knowledgeable way, and so the work here presented is absolutely important.

The study here presented has been developed as part of a research project called ENERWAT, financed by the Portuguese Science and Technology Foundation. One of the project's main aims is to settle the main differences between water and energy consumption in urban and rural households and to evaluate which factors contribute to these differences and how. The root of this project, and indeed the aim of this paper, that involves a survey application and data treatment is to find the factors that in rural and urban environments may justify the differences found in water and energy consumptions. Finding among all the studied factors the ones that differ between environments will show what factors should influence water and energy consumption differences.

\section{Methodology}

\subsection{Study area and sampling}

Vila Real County is located in Northern Portugal, with $378.80 \mathrm{~km}^{2} \mathrm{di}-$ vided between urban and rural land classification (Table 1 ). This county has 20 parishes (Fig. 1), 8 mainly urban (40\%) and 12 mostly rural (60\%), according to the National Statistical Institute (INE, 2015).

It has 327 inhabitants living in places classified as isolated, 21.899 inhabitants residing in places with $<2000$ habitants, and 29.624 inhabitants living in places with $>2000$ habitants (INE, 2015).

Vila Real is a medium-sized municipality integrated in the area of the Douro Valley in the interior North region and plays an important role in the equilibrium of the regional urban system. According to INE (2015), Vila Real urban population presents a relatively young age structure (ageing index of 121), and a medium level of education attainment ( $17 \%$ of population with tertiary education). It also presents a heavily tertiary economy (almost $80 \%$ of the employed population works in this activity sector) but with a relatively low average monthly earning (85\% of the national average) (Matos et al., 2014).

Due to its physiographic location, in 2015 the county experienced temperatures (annual average temperature) between 10.1 and $16.9{ }^{\circ} \mathrm{C}$, and precipitations between $127.8 \mathrm{~mm}$ in October and $0.5 \mathrm{~mm}$ in

Table 1

Land uses distribution in Vila Real County.

\begin{tabular}{llll}
\hline \multicolumn{2}{l}{ Land uses identified in the Municipal Master Plan (PDM) } & \\
\hline \multicolumn{2}{l}{ Urban land (ha) } & & Rural land (ha) \\
\hline Total & Urbanized space & Expansion space & \\
\hline 4497.4 & 3157.7 & 336.4 & $33,380.8$ \\
\hline
\end{tabular}




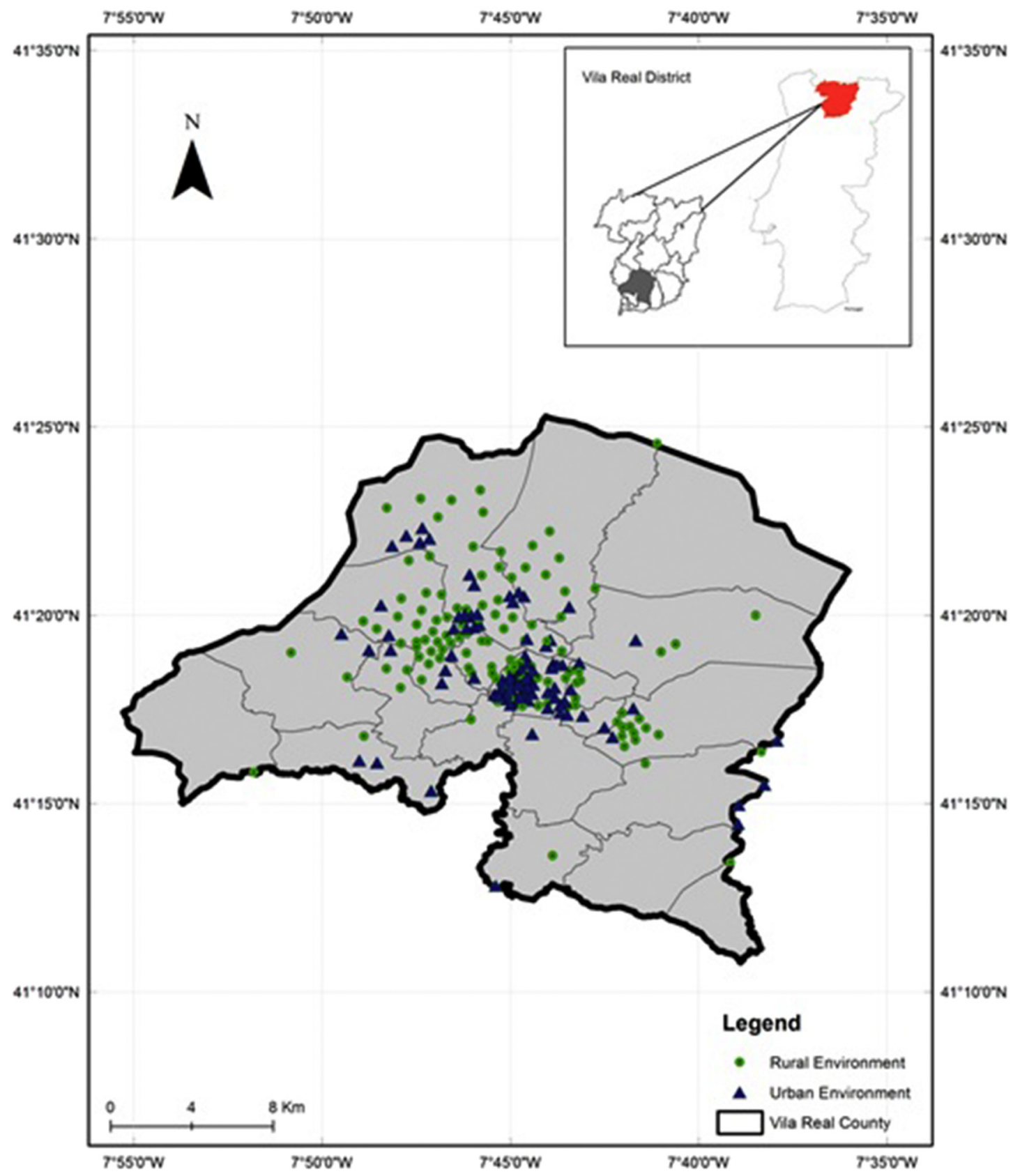

Fig. 1. Sampling location.

March, having had 259 days without precipitation in the same year (data from 2016, issued by the National Statistical Institute), indicating the dryness associated with this region.

In order to choose the houses to sample, some criteria (INE, 2015) were settled in order to classify the environment as rural or urban. So, for rural environment were considered the following sectors:

- Which belong to small villages inserted in the agricultural neighbourhood;

- Which had a population density equal to/or $<100$ inhabitants per $\mathrm{km}^{2}$ at the community level;

- In which the inhabitants have full or part-time primary sector activity.

In relation to urban areas, the following criteria were considered:

- The households would have to be located in a medium/large agglomerate not inserted in the agricultural area;
- The area should have a population density of $>100$ inhabitants per $\mathrm{km}^{2}$ at the community level;

- The inhabitants should have their professional activity in secondary and tertiary sectors.

A sample of households located in Vila Real County was selected. Each household was visited in order to fill out the survey on the spot, so that the researchers could explain relevant issues in person to ensure that the data was accurately collected. Only one person per family unit (independently of gender) answered to the survey, and participation was voluntary.

\subsection{Survey design}

The survey was designed using an online resource named "onlinepesquisa.com" and it was pretested in 40 households (via the pilot survey) in the study area, and additional modifications were 
made based on the results. A face-to-face interview in each household was later performed by two trained interviewers in order to tackle with inconclusive responses and other difficulties emerging from the interpretation of the survey items. The main fieldwork took place between December 2016 and January 2017.

The survey questions were defined in order to obtain information about family composition, household characterization, building information, water and energy consumption habits.

A total of 256 households were surveyed $(\mathrm{N}=256)$. However, 11 surveys were discarded due to missing data. Sometimes the number of answers does not match with the number of surveys concluded. This have two explanations: on one hand, the survey contains questions with sub questions (the sub question is to be answered only if the answer to the main question enables a response in the sub question or due to important missing information), on the other hand, the survey has fields with the "no responses" field (the head of the household had no information to answer).

Hence, a total of 245 urban households ( 110 households, 45\%) and rural ( 135 households, $55 \%$ ) were considered for this research. Because the area is mostly rural, it was easier to perform more surveys in the rural areas, which explains this slight difference in the number of participants.

The final version of the survey integrates 74 questions grouped in six categories: occupant information, building information, energy consumption, water consumption, washing and dishwashing habits, Fig. 2. The questions were elaborated based on the literature review carried out (Binks et al., 2016; Basu et al., 2017; Haziq and Panezai, 2017;
Keshavarzi et al., 2006; Singh and Turkiya, 2013; Hu et al., 2017; Martinez-Santos, 2017; Fan et al., 2017).

Table 2 presents the quantitative (continuous and discrete) and qualitative (categorical/nominal and ordinal) variables that were considered as possible differentiating factors of rural and urban environments. Table 2 also presents the description of the categories of the qualitative variables.

\subsection{Data analysis}

Several statistical analyses were performed to analyze and present the data. The statistical package IBM SPSS23.0 was used for data entry and analysis. Special emphasis was given to the exploratory data analysis. Descriptive statistics (absolute and relative frequency, mean, mode, range, and standard deviation) of the variables across rural and urban environments were used to summarize the survey results and to characterize water and energy consumption in rural and urban households. Considering the nature of the dataset, non-parametric hypothesis tests were applied in order to compare the variables collected in rural and urban households, and to distinguish both environments.

Parametric tests are based on quantitative or even dichotomous measures (proportions), and the use of this type of test requires continuous variables, usually the assumptions of Normal distribution, and homogeneity of variance. In case of failure of at least one of these requirements for the application of these tests, non-parametric tests should be used. Non-parametric tests, when compared with parametric tests, can also be applied to qualitative (categorical/nominal and

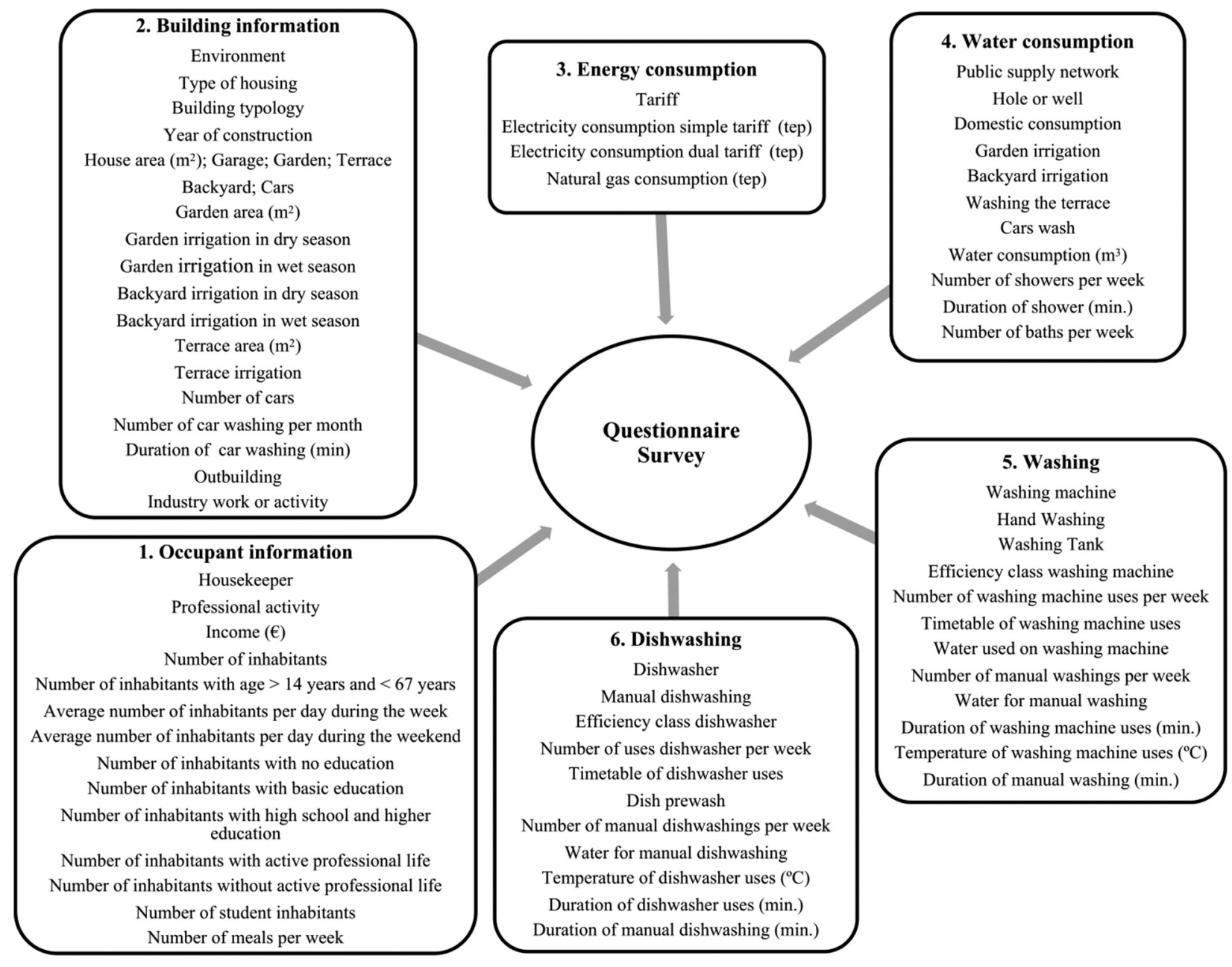

Fig. 2. Categories integrated in the survey. 
Table 2

Description of household variables collected.

\begin{tabular}{|c|c|}
\hline \multicolumn{2}{|l|}{ Variable definition } \\
\hline \multicolumn{2}{|l|}{ 1. Occupant information } \\
\hline \multicolumn{2}{|l|}{ Qualitative variables } \\
\hline Housekeeper & $1=$ yes $; 2=$ no \\
\hline Professional activity & $\begin{array}{l}1=\text { with agricultural, domestic and vineyard } \\
\text { activities } \\
2=\text { without agricultural, domestic and } \\
\text { vineyard activities }\end{array}$ \\
\hline Income $(€)$ & $\begin{array}{l}1=\text { less than } € 500 \\
2=\text { between } € 500 \text { and } € 999 \\
3=\text { between } € 1000 \text { and } € 1999 \\
4=\text { between } € 2000 \text { and } € 3000 \\
5=\text { more than } € 3000\end{array}$ \\
\hline $\begin{array}{l}\text { Quantitative variables } \\
\text { Number of inhabitants } \\
\text { Number of inhabitants with age }> \\
\text { Average number of inhabitants pe } \\
\text { Average number of inhabitants pe } \\
\text { Number of inhabitants with no ed } \\
\text { Number of inhabitants with basic } \\
\text { Number of inhabitants with high } \\
\text { Number of inhabitants with active } \\
\text { Number of inhabitants without ac } \\
\text { Number of student inhabitants } \\
\text { Number of meals per week }\end{array}$ & $\begin{array}{l}14 \text { years and }<67 \text { years } \\
\text { r day during the week } \\
\text { r day during the weekend } \\
\text { ucation } \\
\text { education } \\
\text { chool and higher education } \\
\text { professional life } \\
\text { tive professional life }\end{array}$ \\
\hline \multicolumn{2}{|l|}{ 2. Building information } \\
\hline Environment & $0=$ rural; $1=$ urban \\
\hline Type of housing & $\begin{array}{l}1=\text { multidwelling unit (MDU) } \\
2=\text { single family dwelling (SFD), isolated } \\
3=\text { single family dwelling (SFD), detached }\end{array}$ \\
\hline Year of construction & $\begin{array}{l}1=\text { until } 1990 \\
2=\text { between } 1990 \text { and } 2006 \\
3=\text { between } 2006 \text { and } 2013\end{array}$ \\
\hline House area $\left(\mathrm{m}^{2}\right)$ & $\begin{array}{l}1=\text { less than } 100 \mathrm{~m}^{2} \\
2=\text { between } 100 \mathrm{~m}^{2} \text { and } 200 \mathrm{~m}^{2} \\
3=\text { between } 200 \mathrm{~m}^{2} \text { and } 300 \mathrm{~m}^{2} \\
4=\text { more than } 300 \mathrm{~m}^{2}\end{array}$ \\
\hline Building typology & $1=$ house $;=$ apartment \\
\hline Garage & $1=$ yes; $2=$ no \\
\hline Garden & $1=$ yes; $2=$ no \\
\hline Terrace & $1=$ yes; $2=$ no \\
\hline Backyard & $1=$ yes; $2=$ no \\
\hline Cars & $1=$ yes $; 2=$ no \\
\hline Garden area $\left(\mathrm{m}^{2}\right)$ & $1=$ less than $100 \mathrm{~m}^{2} ; 2=$ more than $100 \mathrm{~m}^{2}$ \\
\hline Garden irrigation in dry season & $1=$ yes; $2=$ no \\
\hline Garden irrigation in wet season & $1=$ yes $; 2=$ no \\
\hline Backyard irrigation in dry season & $1=$ yes; $2=$ no \\
\hline Backyard irrigation in wet season & $1=$ yes $; 2=$ no \\
\hline Terrace area $\left(\mathrm{m}^{2}\right)$ & $\begin{array}{l}1=\text { less than } 10 \mathrm{~m}^{2} \\
2=\text { between } 10 \text { and } 20 \mathrm{~m}^{2} \\
3=\text { more than } 20 \mathrm{~m}^{2}\end{array}$ \\
\hline Terrace irrigation & $1=$ yes; $2=$ no \\
\hline Number of cars & $\begin{array}{l}1=1 \\
2=2 \\
3=3 \\
4=4 \\
5=>4\end{array}$ \\
\hline $\begin{array}{l}\text { Number of car washings per } \\
\text { month }\end{array}$ & $1=0 ; 2=1 ; 3=2$ or more \\
\hline Duration of car washing (min) & $\begin{array}{l}1=\text { less than } 15 \mathrm{~min} \\
2=\text { more than } 15 \mathrm{~min} \\
3=2 \text { or more }\end{array}$ \\
\hline Outbuilding & $1=$ yes; $2=$ no \\
\hline Industry work or activity & $1=$ yes; $2=$ no \\
\hline $\begin{array}{l}\text { 3. Energy consumption } \\
\text { Qualitative variables }\end{array}$ & \\
\hline Tariff & $1=$ simple tariff; $2=$ dual tariff \\
\hline $\begin{array}{l}\text { Electricity consumption simple } \\
\text { tariff (toe) }\end{array}$ & $\begin{array}{l}1=<0.016 \text { toe } \\
2=\text { between } 0.016 \text { toe and } 0.037 \text { toe } \\
3=\text { between } 0.037 \text { toe and } 0.058 \text { toe } \\
4=\text { between } 0.058 \text { toe and } 0.079 \text { toe } \\
5=\text { more than } 0.079 \text { toe }\end{array}$ \\
\hline $\begin{array}{l}\text { Electricity consumption dual } \\
\text { tariff (toe) }\end{array}$ & $\begin{array}{l}1=\text { less than } 0.018 \text { toe } \\
2=\text { between } 0.018 \text { toe and } 0.041 \text { toe }\end{array}$ \\
\hline
\end{tabular}

Table 2 (continued)

\begin{tabular}{|c|c|}
\hline \multicolumn{2}{|l|}{ Variable definition } \\
\hline Natural gas consumption (toe) & $\begin{array}{l}3=\text { between } 0.041 \text { toe and } 0.065 \text { toe } \\
4=\text { between } 0.065 \text { toe and } 0.088 \text { toe } \\
5=\text { more than } 0.088 \text { toe } \\
1=\text { less than } 0.019 \text { toe } \\
2=\text { between } 0.019 \text { toe and } 0.041 \text { toe } \\
3=\text { between } 0.041 \text { toe and } 0.065 \text { toe } \\
4=\text { between } 0.065 \text { toe and } 0.091 \text { ep } \\
5=\text { between } 0.091 \text { toe and } 0.115 \text { toe } \\
6=\text { more than } 0.115 \text { toe }\end{array}$ \\
\hline $\begin{array}{l}\text { 4. Water consumption } \\
\text { Qualitative variables } \\
\text { Public supply network } \\
\text { Water hole or well } \\
\text { Domestic consumption } \\
\text { Garden irrigation } \\
\text { Backyard irrigation } \\
\text { Terrace washing } \\
\text { Car washing } \\
\text { Water consumption }\left(\mathrm{m}^{3}\right)\end{array}$ & $\begin{array}{l}1=\text { yes } 2=\text { no } \\
1=\text { yes; } 2=\text { no } \\
1=\text { public supply network; } 2=\text { hole or well } \\
1=\text { public supply network; } 2=\text { hole or well } \\
1=\text { public supply network } 2=\text { hole or well } \\
1=\text { public supply network; } 2=\text { hole or well } \\
1=\text { public supply network; } 2=\text { hole or well } \\
1=\text { less than } 6 \mathrm{~m}^{3} \\
2=\text { between } 6 \mathrm{~m}^{3} \text { and } 16 \mathrm{~m}^{3} \\
3=\text { between } 16 \mathrm{~m}^{3} \text { and } 22 \mathrm{~m}^{3} \\
4=\text { between } 22 \mathrm{~m}^{3} \text { and } 27 \mathrm{~m}^{3} \\
5=\text { between } 27 \mathrm{~m}^{3} \text { and } 34 \mathrm{~m}^{3} \\
6=\text { more than } 34 \mathrm{~m}^{3}\end{array}$ \\
\hline $\begin{array}{l}\text { Quantitative variables } \\
\text { Number of showers per week } \\
\text { Duration of shower (min) } \\
\text { Number of baths per week }\end{array}$ & \\
\hline $\begin{array}{l}\text { 5. Washing } \\
\text { Qualitative variables }\end{array}$ & \\
\hline $\begin{array}{l}\text { Washing machine } \\
\text { Clothes manual washing } \\
\text { Washing tank } \\
\text { Efficiency class washing machine }\end{array}$ & $\begin{array}{l}1=\text { yes } 2=\text { no } \\
1=\text { yes; } 2=\text { no } \\
1=\text { yes; } 2=\text { no } \\
1=A+++ \\
2=A++ \\
3=A+ \\
4=A \\
5=B\end{array}$ \\
\hline $\begin{array}{l}\text { Number of washing machine } \\
\text { uses per week }\end{array}$ & $\begin{array}{l}1=0 \\
2=1 \text { to } 3 \\
3=4 \text { to } 6 \\
4=7 \text { to } 10 \\
5=\text { more than } 10\end{array}$ \\
\hline $\begin{array}{l}\text { Timetable of washing machine } \\
\text { uses }\end{array}$ & $\begin{array}{l}1=8: 00 \mathrm{am}-11: 59 \mathrm{am} \\
2=12: 00 \mathrm{am}-07: 59 \mathrm{pm} \\
3=08: 00 \mathrm{pm}-7: 59 \mathrm{am} \\
4=\text { random }\end{array}$ \\
\hline $\begin{array}{l}\text { Water used in the washing } \\
\text { machine }\end{array}$ & $\begin{array}{l}1=\text { cold water } \\
2=\text { warm water } \\
3=\text { cold and warm water }\end{array}$ \\
\hline $\begin{array}{l}\text { Number of manual washings per } \\
\text { week } \\
\text { Water for manual washing }\end{array}$ & $\begin{array}{l}1=0 ; 2=1 \\
3=\text { more than } 1 \\
1=\text { cold water } \\
2=\text { cold and warm water }\end{array}$ \\
\hline $\begin{array}{l}\text { Quantitative variables } \\
\text { Duration of washing machine uses } \\
\text { Temperature of washing machine } \\
\text { Duration of manual washing (min) }\end{array}$ & $\begin{array}{l}(\min ) \\
\text { ases }\left({ }^{\circ} \mathrm{C}\right)\end{array}$ \\
\hline $\begin{array}{l}\text { 6. Dishwashing } \\
\text { Qualitative variables }\end{array}$ & \\
\hline $\begin{array}{l}\text { Dishwasher } \\
\text { Manual dishwashing } \\
\text { Efficiency class dishwasher }\end{array}$ & $\begin{array}{l}1=\text { yes } 2=\text { no } \\
1=\text { yes } 2=\text { no } \\
1=A+++ \\
2=A++ \\
3=A+ \\
4=A \\
5=B\end{array}$ \\
\hline $\begin{array}{l}\text { Number of dishwasher uses per } \\
\text { week }\end{array}$ & $\begin{array}{l}1=0 \\
2=1 \text { to } 3 \\
3=4 \text { to } 6 \\
4=\text { more than } 7\end{array}$ \\
\hline Timetable of dishwasher uses & $\begin{array}{l}1=8: 00 \mathrm{am}-11: 59 \mathrm{am} \\
2=12: 00 \mathrm{am}-07: 59 \mathrm{pm} \\
3=08: 00 \mathrm{pm}-7: 59 \mathrm{am}\end{array}$ \\
\hline
\end{tabular}


Table 2 (continued)

\begin{tabular}{|c|c|}
\hline \multicolumn{2}{|l|}{ Variable definition } \\
\hline \multirow{3}{*}{ Dish prewash } & $4=$ random \\
\hline & $1=$ no \\
\hline & $2=$ yes, manually \\
\hline \multirow{5}{*}{$\begin{array}{l}\text { Number of manual dishwashing } \\
\text { per week }\end{array}$} & $3=$ yes, in the machine \\
\hline & $1=0$ \\
\hline & $2=1$ to 3 \\
\hline & $3=4$ to 6 \\
\hline & $4=7$ to 10 \\
\hline \multirow{3}{*}{ Water for manual dishwashing } & $5=$ more than 10 \\
\hline & $1=$ cold water \\
\hline & $2=$ cold and warm water \\
\hline \multicolumn{2}{|l|}{ Quantitative variables } \\
\hline \multicolumn{2}{|l|}{ Temperature of dishwasher uses $\left({ }^{\circ} \mathrm{C}\right)$} \\
\hline \multicolumn{2}{|c|}{ Duration of dishwasher uses (min) } \\
\hline \multicolumn{2}{|c|}{ Duration of manual dishwashing (min) } \\
\hline
\end{tabular}

ordinal) variables, they require fewer assumptions for distributions, they are very useful for the analysis of large samples where parametric assumptions do not occur, and also for very small samples (Conover, 1998).

In this study, due to the nature of the observed variables and respective distributions, two non-parametric hypothesis tests were performed: the Mann-Whitney-Wilcoxon test and the Chi-square test of homogeneity.

The non-parametric Mann-Whitney-Wilcoxon hypothesis test is applied when comparing outcomes between two independent populations, in order to detect if the distributions are equal or to detect changes in location (median); it is important to note that the null hypothesis is the same for both. This test is used as an alternative to the $t$ (parametric) test for the equality of two means of independent samples (for quantitative variables), when it cannot be applied due to violation of the assumptions, namely that of normality or when there is no information about the theoretical distributions. The non-parametric Chisquare test of homogeneity is applied to a single qualitative (categorical or ordinal) variable from two or more different populations. It is used to determine whether frequency counts are identically distributed across different populations, i.e. for testing whether two or more multinomial distributions are equal (Higgins, 2004).

In this study, two populations are considered: rural and urban populations.

The results from the statistical tests were evaluated using the $5 \%$ significance level as the threshold for distinguishing between "not statistically significant" and the opposite. It is worth stressing that the results of some of these tests will not be reported here.

\section{Descriptive statistics analysis and non-parametric hypothesis tests}

In this section, it will be presented the results of the descriptive analysis and the results of the data comparison between the two groups through the analysis of the statistical non-parametric tests performance.

Descriptive statistics of the variables are presented in Tables 3 and 4 for quantitative and qualitative variables, respectively, in rural and urban regions. These variables/factors were statistically significant in the differentiation of the behavior of their distributions in the rural (Group I (R)) and urban (Group II (U)) environments analyzed, as a result of the application of non-parametric hypothesis tests. The results of the performed non-parametric tests, where the differences between the two environments are highlighted, are presented from Tables 5 to 11.

\subsection{Occupant information}

Table 5 indicates that the majority of the households in both studied environments doesn't have "Housekeeper", the two groups assumed "no housekeeper" as modal category, with 94.1\% in group I (Rural) and $79.1 \%$ in group II (Urban). Also, at 0.05 significance level, there is enough statistical evidence to state that the frequency counts of "Housekeeper" are not identically distributed across the two environments (test statistic $\chi 2(1)=12.312, p$-value $<0.001)$, i.e. environment influences the multinomial distributions of "Housekeeper". As expected, and although the results presented, in the urban environment is more common to have housekeeper than in the rural one.

The majority of professional activity of the household head is associated to "No agricultural, domestic and vineyard activities" in both environments (rural and urban), with $71.1 \%$ in Group I (Rural) and $97.3 \%$ in Group II (Urban).

It was found that the household head with professional activity "No/ With agricultural, domestic and vineyard activities" in rural areas distributes differently from those in urban areas $(\chi 2(1)=29.206, p$ value $<0.001$ ), i.e., environment influences the multinomial distributions of "No/with agricultural, domestic and vineyard activities". It would be expected that in rural areas the main professional activity would be the "agriculture or domestic activity" and, as this region is located in Douro region, the activity "vineyard" would have a great percentages of responses. The obtained results can be explained by the geographical proximity to Vila Real urban area and so, the main activities of the households are not linked to the primary sector. Although there is a slight difference between rural and urban in this variable and the main number of responses as "with agricultural..." belongs to the rural environment (39 to 3 in urban environment-Table 4).

Table 3

Description of household characteristics using quantitative (continuous and discrete) variables.

\begin{tabular}{|c|c|c|c|c|c|c|c|c|c|c|}
\hline \multirow[t]{2}{*}{ Variable definition } & \multicolumn{2}{|l|}{$\mathrm{N}$} & \multicolumn{2}{|l|}{ Range } & \multicolumn{2}{|c|}{ Mean } & \multicolumn{2}{|c|}{ Mode } & \multicolumn{2}{|c|}{ Std. dev. } \\
\hline & $\mathrm{R}$ & $\mathrm{U}$ & $\mathrm{R}$ & $\mathrm{U}$ & $\mathrm{R}$ & $\mathrm{U}$ & $\mathrm{R}$ & $\mathrm{U}$ & $\mathrm{R}$ & $\mathrm{U}$ \\
\hline Average number of inhabitants per day during the week & 135 & 110 & $1-6$ & $0-4$ & 2.2 & 1.70 & 2 & 1 & 0.91 & 0.91 \\
\hline Average number of inhabitants per day during the weekend & 135 & 110 & $1-7$ & $0-6$ & 2.8 & 2.20 & 2 & 2 & 1.19 & 1.32 \\
\hline Number of inhabitants with no education & 135 & 110 & $0-2$ & $0-1$ & 0.1 & 0.03 & 0 & 0 & 0.39 & 0.16 \\
\hline Number of inhabitants with basic education & 135 & 110 & $0-6$ & $0-6$ & 1.8 & 0.70 & 2 & 0 & 1.09 & 1.03 \\
\hline Number of inhabitants with high school and higher education & 135 & 110 & $0-4$ & $0-5$ & 1.0 & 1.90 & 0 & 2 & 1.04 & 0.98 \\
\hline Number of inhabitants with active professional life & 135 & 110 & $0-5$ & $0-4$ & 1.2 & 1.50 & 0 & 2 & 1.18 & 0.81 \\
\hline Number of inhabitants without active professional life & 135 & 110 & $0-4$ & $0-3$ & 1.4 & 0.60 & 2 & 0 & 1.05 & 0.80 \\
\hline Number of meals per week & 135 & 110 & $2-24$ & $0-45$ & 16.7 & 11.20 & 21 & 14 & 5.68 & 6.45 \\
\hline Number of showers per week & 135 & 110 & $1-50$ & $3-50$ & 13.9 & 15.90 & 4 & 14 & 9.69 & 9.00 \\
\hline Number of baths per week & 135 & 110 & $0-10$ & $0-50$ & 0.3 & 1.70 & 0 & 0 & 1.21 & 6.23 \\
\hline Duration of washing machine uses (min) & 121 & 102 & $15-240$ & $25-180$ & 86.8 & 78.10 & 90 & 60 & 32.07 & 37.45 \\
\hline Duration of manual washing (min) & 58 & 22 & $5-60$ & $5-30$ & 22.9 & 12.10 & 20 & 10 & 11.43 & 5.91 \\
\hline Temperature of dishwasher uses $\left({ }^{\circ} \mathrm{C}\right)$ & 50 & 60 & $30-80$ & $10-100$ & 45.4 & 53.50 & 40 & 60 & 12.16 & 15.60 \\
\hline Duration of dishwasher uses (min) & 56 & 70 & $30-180$ & $29-185$ & 65.5 & 82.50 & 60 & 60 & 38.01 & 42.62 \\
\hline Duration of manual dishwashing (min) & 120 & 89 & $5-30$ & $2-40$ & 16.3 & 13.40 & 20 & 15 & 5.31 & 6.37 \\
\hline
\end{tabular}


Table 4

Description of household characteristics using qualitative (categorical and ordinal) variables.

\begin{tabular}{|c|c|c|c|c|c|}
\hline \multirow[t]{2}{*}{ Variable definition } & \multirow[t]{2}{*}{ Categories } & \multicolumn{2}{|l|}{ Frequency } & \multicolumn{2}{|l|}{$\mathrm{N}$} \\
\hline & & $\mathrm{R}$ & $\mathrm{U}$ & $\mathrm{R}$ & $\mathrm{U}$ \\
\hline \multirow[t]{2}{*}{ Housekeeper } & $1=$ yes & $8(5.9 \%)$ & $23(20.9 \%)$ & 135 & 110 \\
\hline & $2=$ no & $127(94.1 \%)$ & $87(79.1 \%)$ & & \\
\hline \multirow[t]{2}{*}{ Professional activity } & $1=$ with agricultural, domestic and vineyard activities & $39(28.9 \%)$ & $3(2.7 \%)$ & 135 & 110 \\
\hline & $2=$ no agricultural, domestic and vineyard activities & $96(71.1 \%)$ & $107(97.3 \%)$ & & \\
\hline \multirow[t]{5}{*}{ Income $(€)$} & $1=$ less than $€ 500$ & $22(16.3 \%)$ & $2(1.8 \%)$ & 135 & 110 \\
\hline & $2=$ between $€ 500$ and $€ 999$ & $60(44.4 \%)$ & $26(23.6 \%)$ & & \\
\hline & $3=$ between $€ 1000$ and $€ 1999$ & $37(27.4 \%)$ & $51(46.4 \%)$ & & \\
\hline & $4=$ between $€ 2000$ and $€ 3000$ & $13(9.6 \%)$ & $19(17.3 \%)$ & & \\
\hline & $5=$ more than $3000 €$ & $3(2.2 \%)$ & $12(10.9 \%)$ & & \\
\hline \multirow[t]{3}{*}{ Type of housing } & $1=$ multi-family housing & $5(3.7 \%)$ & $77(70.0 \%)$ & 135 & 110 \\
\hline & $2=$ single family dwelling, isolated & $94(69.6 \%)$ & $16(14.5 \%)$ & & \\
\hline & $3=$ single family dwelling, twinned & $36(26.7 \%)$ & $17(15.5 \%)$ & & \\
\hline \multirow[t]{3}{*}{ Year of construction } & $1=$ until 1990 & $86(64.7 \%)$ & $39(53.2 \%)$ & 133 & 102 \\
\hline & $2=$ between 1990 and 2006 & $40(30.1 \%)$ & $49(48.0 \%)$ & & \\
\hline & $3=$ between 2006 and 2013 & $7(5.3 \%)$ & $14(13.7 \%)$ & & \\
\hline \multirow[t]{4}{*}{ House area $\left(\mathrm{m}^{2}\right)$} & $1=$ less than $100 \mathrm{~m}^{2}$ & $27(22.1 \%)$ & $28(29.2 \%)$ & 122 & 96 \\
\hline & $2=$ between $100 \mathrm{~m}^{2}$ and $200 \mathrm{~m}^{2}$ & $48(39.3 \%)$ & $47(49.0 \%)$ & & \\
\hline & $3=$ between $200 \mathrm{~m}^{2}$ and $300 \mathrm{~m}^{2}$ & $27(22.1 \%)$ & $13(13.5 \%)$ & & \\
\hline & $4=$ more than $300 \mathrm{~m}^{2}$ & $20(16.4 \%)$ & $8(8.3 \%)$ & & \\
\hline Building typology & $1=$ house & $130(96.3 \%)$ & $32(29.1 \%)$ & 135 & 110 \\
\hline & $2=$ apartment & $5(3.7 \%)$ & $78(70.9 \%)$ & & \\
\hline Garden & $1=$ yes & $77(57.0 \%)$ & $29(26.4 \%)$ & 135 & 110 \\
\hline & $2=$ no & $58(43.0 \%)$ & $81(73.6 \%)$ & & \\
\hline Terrace & $1=$ yes & $86(63.7 \%)$ & $57(51.8 \%)$ & 135 & 110 \\
\hline & $2=$ no & $49(36.3 \%)$ & $53(48.2 \%)$ & & \\
\hline Backyard & $1=$ yes & $68(50.4 \%)$ & $13(11.8 \%)$ & 135 & 110 \\
\hline & $2=$ no & $67(49.6 \%)$ & $97(88.2 \%)$ & & \\
\hline Terrace area $\left(\mathrm{m}^{2}\right)$ & $1=$ less than $10 \mathrm{~m}^{2}$ & $27(31.0 \%)$ & $28(49.1 \%)$ & 87 & 57 \\
\hline & $2=$ between 10 and $20 \mathrm{~m}^{2}$ & $40(46.0 \%)$ & $18(31.6 \%)$ & & \\
\hline & $3=$ more than $20 \mathrm{~m}^{2}$ & $20(23.0 \%)$ & $11(19.3 \%)$ & & \\
\hline Number of car washings per month & $1=0$ & $38(39.2 \%)$ & $62(79.5 \%)$ & 97 & 78 \\
\hline & $2=1$ & $46(47.4 \%)$ & $8(10.3 \%)$ & & \\
\hline & $3=2$ or more & $13(13.4 \%)$ & $8(10.3 \%)$ & & \\
\hline Tariff & $1=$ simple tariff & $121(89.6 \%)$ & $84(76.4 \%)$ & 135 & 110 \\
\hline & $2=$ dual tariff & $14(10.4 \%)$ & $26(23.6 \%)$ & & \\
\hline Public supply network & $1=$ yes & $121(89.6 \%)$ & $110(100 \%)$ & 135 & 110 \\
\hline & $2=$ no & $14(10.4 \%)$ & $0(0.0 \%)$ & & \\
\hline Water hole or well & $1=$ yes & $42(31.1 \%)$ & $8(7.3 \%)$ & 135 & 110 \\
\hline & $2=$ no & $93(68.9 \%)$ & $102(92.7 \%)$ & & \\
\hline Domestic consumption & $1=$ public supply network & $118(88.7 \%)$ & $110(100 \%)$ & 133 & 110 \\
\hline & $2=$ hole or well & $15(11.3 \%)$ & $0(0.0 \%)$ & & \\
\hline Garden irrigation & $1=$ public supply network & $23(40.4 \%)$ & $17(68.0 \%)$ & 57 & 25 \\
\hline & $2=$ hole or well & $34(59.6 \%)$ & $8(32.0 \%)$ & & \\
\hline Terrace washing & $1=$ public supply network & $24(44.4 \%)$ & $35(79.5 \%)$ & 54 & 44 \\
\hline & $2=$ hole or well & $30(55.6 \%)$ & $9(20.5 \%)$ & & \\
\hline Manual washing & $1=$ yes & $59(43.7 \%)$ & $22(20.2 \%)$ & 135 & 109 \\
\hline & $2=$ no & $76(56.3 \%)$ & $87(79.8 \%)$ & & \\
\hline Clothes manual washing & $1=$ yes & $36(26.7 \%)$ & $18(16.4 \%)$ & 135 & 110 \\
\hline & $2=$ no & $99(73.3 \%)$ & $92(83.6 \%)$ & & \\
\hline Efficiency class washing machine & $1=\mathrm{A}+++$ & $6(5.0 \%)$ & $16(16.0 \%)$ & 119 & 100 \\
\hline & $2=\mathrm{A}++$ & $12(10.1 \%)$ & $40(40.0 \%)$ & & \\
\hline & $3=\mathrm{A}+$ & $64(53.8 \%)$ & $31(31.0 \%)$ & & \\
\hline & $4=\mathrm{A}$ & $31(26.1 \%)$ & $10(10.0 \%)$ & & \\
\hline & $5=\mathrm{B}$ & $6(5.0 \%)$ & $3(3.0 \%)$ & & \\
\hline Timetable of washing machine uses & $1=08: 00 \mathrm{am}-11: 59 \mathrm{am}$ & $7(5.7 \%)$ & $8(7.7 \%)$ & 122 & 104 \\
\hline & $2=12: 00 \mathrm{am}-07: 59 \mathrm{pm}$ & $6(4.9 \%)$ & $8(6.4 \%)$ & & \\
\hline & $3=08: 00 \mathrm{pm}-07: 59 \mathrm{am}$ & $15(12.3 \%)$ & $32(30.8 \%)$ & & \\
\hline & $4=$ random & $94(77.0 \%)$ & $56(53.8 \%)$ & & \\
\hline Water for manual washing & $1=$ cold water & $49(83.1 \%)$ & $5(23.8 \%)$ & 59 & 21 \\
\hline & $2=$ cold and warm water & $10(16.9 \%)$ & $16(76.2 \%)$ & & \\
\hline Dishwasher & $1=$ yes & $59(43.7 \%)$ & $70(63.6 \%)$ & 135 & 110 \\
\hline & $2=$ no & $76(56.3 \%)$ & $40(36.4 \%)$ & & \\
\hline Manual dishwashing & $1=$ yes & $122(90.4 \%)$ & $90(81.8 \%)$ & 135 & 110 \\
\hline & $2=$ no & $13(9.6 \%)$ & $20(18.2 \%)$ & & \\
\hline Number of manual dishwashings & $1=0$ & $2(1.7 \%)$ & $0(0.0 \%)$ & 121 & 89 \\
\hline & $2=1$ to 3 & $14(11.6 \%)$ & $12(13.5 \%)$ & & \\
\hline & $3=4$ to 6 & $9(7.4 \%)$ & $16(18.0 \%)$ & & \\
\hline & $4=7$ to 10 & $65(53.7 \%)$ & $28(31.5 \%)$ & & \\
\hline & $5=$ more than 10 & $31(25.6 \%)$ & $33(37.1 \%)$ & & \\
\hline Manual washing use of water & $1=$ cold water & $50(41.7 \%)$ & $24(27.0 \%)$ & 120 & 89 \\
\hline & $2=$ cold and warm water & $70(58.3 \%)$ & $65(73.0 \%)$ & & \\
\hline
\end{tabular}


Table 5

Comparison of rural and urban environment distributions relating to "Housekeeper", "Professional activity", and "Income".

\begin{tabular}{|c|c|c|c|c|}
\hline & & $\begin{array}{l}\text { Group I } \\
\text { (Rural) }\end{array}$ & $\begin{array}{l}\text { Group II } \\
\text { (Urban) }\end{array}$ & $p$-Value ${ }^{\mathrm{a}}$ \\
\hline Housekeeper & Yes & & & $p<$ \\
\hline Total & Obs. Freq. & $8(5.9 \%)$ & $23(20.9 \%)$ & 0.001 \\
\hline Group I: 135 & Standardized residuals & -2.2 & 2.4 & \\
\hline \multirow[t]{3}{*}{ Group II: 110} & No & & & \\
\hline & Obs. Freq. & $\begin{array}{l}127 \\
(94.1 \%)\end{array}$ & $87(79.1 \%)$ & \\
\hline & Standardized residuals & 0.8 & -0.9 & \\
\hline $\begin{array}{l}\text { Professional } \\
\text { activity }\end{array}$ & $\begin{array}{l}\text { With agricultural, } \\
\text { domestic }\end{array}$ & & & $\begin{array}{l}p< \\
0.001\end{array}$ \\
\hline Total & and vineyard activities & & & \\
\hline Group I: 135 & Obs. Freq. & $39(28.9 \%)$ & $3(2.7 \%)$ & \\
\hline \multirow[t]{3}{*}{ Group II: 110} & $\begin{array}{l}\text { Standardized residuals } \\
\text { No agricultural, domestic } \\
\text { and vineyard activities }\end{array}$ & 3.3 & -3.7 & \\
\hline & Obs. Freq. & $96(71.1 \%)$ & $\begin{array}{l}107 \\
(97.3 \%)\end{array}$ & \\
\hline & Standardized residuals & -1.5 & 1.7 & \\
\hline Income & Less than $€ 500$ & & & $p<$ \\
\hline Total & Obs. Freq. & $22(16.3 \%)$ & $2(1.8 \%)$ & 0.001 \\
\hline Group I: 135 & Standardized residuals & 2.4 & -2.7 & \\
\hline \multirow[t]{11}{*}{ Group II: 110} & Between $€ 500$ and $€ 999$ & & & \\
\hline & Obs. Freq. & $60(44.4 \%)$ & $26(23.6 \%)$ & \\
\hline & Standardized residuals & 1.8 & -2 & \\
\hline & Between $€ 1000$ and $€ 1999$ & & & \\
\hline & Obs. Freq. & $37(27.4 \%)$ & $51(46.4 \%)$ & \\
\hline & Standardized residuals & -1.7 & 1.8 & \\
\hline & Between $€ 2000$ and $€ 3000$ & & & \\
\hline & Obs. Freq. & $13(9.6 \%)$ & $19(17.3 \%)$ & \\
\hline & $\begin{array}{l}\text { Residuals standardized } \\
\text { More than } € 3000\end{array}$ & -1.1 & 1.2 & \\
\hline & Obs. Freq. & $3(2.2 \%)$ & $12(10.9 \%)$ & \\
\hline & Standardized residuals & -1.8 & 2 & \\
\hline
\end{tabular}

a Chi-square test.

Considering household incomes, it is observed from Table 5 that the "Less than $€ 500$ " category is primarily responsible for the nonhomogeneity of the proportion of elements in the two environments in the different categories: $16.3 \%$ of the rural households earn "Less than $€ 500$ " versus $1.8 \%$ corresponding to two urban households ( $\chi 2$ $(4)=36.692$, $p$-value $<0.001)$. In fact, the "Less than $€ 500$ " category presents a proportion of rural environment households larger than the expected frequency. This discrepancy remains, although a little less pronounced in the "Between $€ 500$ and €999" category, reversing completely when is analyzed the data from categories "Between $€ 1000$ and €1999", "Between $€ 2000$ and $€ 3000 "$, and "More than $€ 3000$ ". The observed frequency of Group I is lower than the expected frequency.

The data analysis indicates that household incomes are lower in a rural environment: about half of the respondents (44.4\%) earn "Between $€ 500$ and $€ 999$ ", whereas almost half of respondents (46.4\%) in an urban environment earn "Between $€ 1000$ and $€ 1999$ ". Only $2.2 \%$ of the household income in a rural environment is "More than $€ 3000$ ", but $10.9 \%$ in an urban environment.

The average number of inhabitants per day during the week in the housing ranges from 1 to 6 (with a mean of 2.2) in rural areas, and this value is higher than the urban average, which is 0 to 4 (with a mean of 1.7) (Table 3), although the data dispersion in both environments is similar (both distributions with a standard deviation 0.91: there is a variation of about one inhabitant per day around the mean). Note that in Group I (Rural) the most frequent number of inhabitants per day during the week is 2 inhabitants, while in Group II (Urban) is only 1 people (mode $=2$ and mode $=1$ ). In order to examine the behavior of the average number of inhabitants per day during the week by environment, a Mann-Whitney-Wilcoxon test was computed. There was statistically significant evidence at $\alpha=0.05$ to conclude that the two population distributions (rural and urban) of the average
Table 6

Comparison of rural and urban environment distributions relating to "Type of housing", "Year of construction", “House area”, "Building typology”, and "Garden”.

\begin{tabular}{|c|c|c|c|c|}
\hline & & $\begin{array}{l}\text { Group I } \\
\text { (Rural) }\end{array}$ & $\begin{array}{l}\text { Group II } \\
\text { (Urban) }\end{array}$ & $p$-Value* \\
\hline \multirow{10}{*}{$\begin{array}{l}\text { Type of housing } \\
\text { Total } \\
\text { Group I: } 135 \\
\text { Group II: } 110\end{array}$} & MDU & & & \multirow[t]{10}{*}{$p<0.001$} \\
\hline & Obs. Freq. & $5(3.7 \%)$ & $77(70.0 \%)$ & \\
\hline & Standardized & -6.0 & 6.6 & \\
\hline & residuals & & & \\
\hline & SFU, isolated & & & \\
\hline & Obs. Freq. & $94(69.6 \%)$ & $16(14.5 \%)$ & \\
\hline & $\begin{array}{l}\text { Standardized } \\
\text { residuals }\end{array}$ & 4.3 & -4.8 & \\
\hline & SFU, twinned & & & \\
\hline & Obs. Freq. & $36(26.7 \%)$ & $17(15.5 \%)$ & \\
\hline & $\begin{array}{l}\text { Standardized } \\
\text { residuals }\end{array}$ & 1.3 & -1.4 & \\
\hline \multirow{2}{*}{$\begin{array}{l}\text { Year of } \\
\text { construction }\end{array}$} & Until 1990 & & & \multirow[t]{10}{*}{$p<0.001$} \\
\hline & Obs. Freq. & $86(64.7 \%)$ & $39(53.2 \%)$ & \\
\hline Total & Standardized & 1.8 & -2.1 & \\
\hline Group I: 133 & residuals & & & \\
\hline \multirow[t]{6}{*}{ Group II: 102} & $\begin{array}{l}\text { Between } 1990 \text { and } \\
2006\end{array}$ & & & \\
\hline & Obs. Freq. & $40(30.1 \%)$ & $49(48.0 \%)$ & \\
\hline & $\begin{array}{l}\text { Standardized } \\
\text { residuals }\end{array}$ & -1.5 & 1.7 & \\
\hline & $\begin{array}{l}\text { Between } 2006 \text { and } \\
2013\end{array}$ & & & \\
\hline & Obs. Freq. & $7(5.3 \%)$ & $14(13.7 \%)$ & \\
\hline & $\begin{array}{l}\text { Standardized } \\
\text { residuals }\end{array}$ & -1.4 & 1.6 & \\
\hline House area & Less than $100 \mathrm{~m}^{2}$ & & & \multirow{13}{*}{$\begin{array}{l}p^{\mathrm{a}}= \\
0.070\end{array}$} \\
\hline Total & Obs. Freq. & $27(22.1 \%)$ & $28(29.2 \%)$ & \\
\hline Group I: 122 & Standardized & -0.7 & 0.8 & \\
\hline \multirow[t]{10}{*}{ Group II: 96} & residuals & & & \\
\hline & \multicolumn{3}{|c|}{ Between $100 \mathrm{~m}^{2}$ and $200 \mathrm{~m}^{2}$} & \\
\hline & Obs. Freq. & $48(39.3 \%)$ & $47(49.0 \%)$ & \\
\hline & $\begin{array}{l}\text { Standardized } \\
\text { residuals }\end{array}$ & -0.7 & 0.8 & \\
\hline & \multicolumn{3}{|c|}{ Between $200 \mathrm{~m}^{2}$ and $300 \mathrm{~m}^{2}$} & \\
\hline & Freq Obs & $27(22.1 \%)$ & $13(13.5 \%)$ & \\
\hline & $\begin{array}{l}\text { Standardized } \\
\text { residuals }\end{array}$ & 1.0 & -1.1 & \\
\hline & More than $300 \mathrm{~m}^{2}$ & & & \\
\hline & Freq Obs & $20(16.4 \%)$ & $8(8.3 \%)$ & \\
\hline & $\begin{array}{l}\text { Standardized } \\
\text { residuals }\end{array}$ & 1.1 & -1.2 & \\
\hline \multirow{2}{*}{$\begin{array}{l}\text { Building } \\
\text { typology }\end{array}$} & House & & & \multirow[t]{7}{*}{$p<0.001$} \\
\hline & Freq Obs & 130 (96.3\%) & $32(29.1 \%)$ & \\
\hline Total & Standardized & 4.3 & -4.8 & \\
\hline Group I: 135 & residuals & & & \\
\hline \multirow[t]{3}{*}{ Group II: 110} & Apartment & & & \\
\hline & Freq Obs & $5(3.7 \%)$ & 78 (70.9\%) & \\
\hline & $\begin{array}{l}\text { Standardized } \\
\text { residuals }\end{array}$ & -6.0 & 6.7 & \\
\hline Garden & Yes & & & \multirow[t]{7}{*}{$p<0.001$} \\
\hline Total & Freq Obs & 77 (57.0\%) & $29(26.4 \%)$ & \\
\hline Group I: 135 & Standardized & 2.4 & -2.7 & \\
\hline \multirow[t]{4}{*}{ Group II: 110} & residuals & & & \\
\hline & No & & & \\
\hline & Freq Obs & $58(43.0 \%)$ & $81(73.6 \%)$ & \\
\hline & $\begin{array}{l}\text { Standardized } \\
\text { residuals }\end{array}$ & -2.1 & 2.4 & \\
\hline
\end{tabular}

* Chi-square test.

a Significant at the 0.10 level.

number of inhabitants per day during the week are not equal ( $p$-value $<0.001)$.

The average number of inhabitants per day during the weekend ranges between 1 and 7 (with a mean of 2.8, about 3 inhabitants) in a rural environment, and between 0 and 6 (with a mean of 2.2, about 2 inhabitants) in an urban environment. There were found significant differences (medians) in the distributions of the average number of inhabitants per day during the weekend in rural and urban areas ( $p$ value $=0.002$ ). 
Table 7

Comparison of rural and urban environment distributions relating to "Terrace", "Backyard", "Terrace area", and "Number of car washings per month".

\begin{tabular}{|c|c|c|c|c|}
\hline & & $\begin{array}{l}\text { Group I } \\
\text { (Rural) }\end{array}$ & $\begin{array}{l}\text { Group II } \\
\text { (Urban) }\end{array}$ & $p$-Value* \\
\hline Terrace & Yes & & & $p^{\mathrm{a}}=$ \\
\hline Total & Obs. Freq. & 86 & 57 & 0.060 \\
\hline Group I: 135 & & $(63.7 \%)$ & $(51.8 \%)$ & \\
\hline \multirow[t]{3}{*}{ Group II: 110} & $\begin{array}{l}\text { Standardized } \\
\text { residuals } \\
\text { No }\end{array}$ & 0.8 & -0.9 & \\
\hline & Obs. Freq. & $\begin{array}{l}49 \\
(36.3 \%)\end{array}$ & $\begin{array}{l}53 \\
(48.2 \%)\end{array}$ & \\
\hline & $\begin{array}{l}\text { Standardized } \\
\text { residuals }\end{array}$ & -1.0 & 1.1 & \\
\hline Backyard & Yes & & & $p<$ \\
\hline Total & Obs. Freq. & 68 & 13 & 0.001 \\
\hline Group I: 135 & & $(50.4 \%)$ & $(11.8 \%)$ & \\
\hline \multirow[t]{3}{*}{ Group II: 110} & $\begin{array}{l}\text { Standardized } \\
\text { residuals } \\
\text { No }\end{array}$ & 3.5 & -3.9 & \\
\hline & Obs. Freq. & $\begin{array}{l}67 \\
(49.6 \%)\end{array}$ & $\begin{array}{l}97 \\
(88.2 \%)\end{array}$ & \\
\hline & $\begin{array}{l}\text { Standardized } \\
\text { residuals }\end{array}$ & -2.5 & 2.7 & \\
\hline Terrace area & Less than $10 \mathrm{~m}^{2}$ & & & $p^{\mathrm{a}}=$ \\
\hline Total & Obs. Freq. & 27 & 28 & 0.085 \\
\hline Group I: 87 & & $(31.0 \%)$ & $(49.1 \%)$ & \\
\hline \multirow[t]{7}{*}{ Group II: 57} & $\begin{array}{l}\text { Standardized } \\
\text { residuals }\end{array}$ & -1.1 & 1.3 & \\
\hline & $\begin{array}{l}\text { Between } 10 \text { and } \\
20 \mathrm{~m}^{2}\end{array}$ & & & \\
\hline & Obs. Freq. & $\begin{array}{l}40 \\
(46.0 \%)\end{array}$ & $\begin{array}{l}18 \\
(31.6 \%)\end{array}$ & \\
\hline & $\begin{array}{l}\text { Standardized } \\
\text { residuals }\end{array}$ & 0.8 & -1.0 & \\
\hline & More than $20 \mathrm{~m}^{2}$ & & & \\
\hline & Obs. Freq. & $\begin{array}{l}20 \\
(23.0 \%)\end{array}$ & $\begin{array}{l}11 \\
(19.3 \%)\end{array}$ & \\
\hline & $\begin{array}{l}\text { Standardized } \\
\text { residuals }\end{array}$ & 0.3 & -0.4 & \\
\hline Number of car washings per & 0 & & & $p<$ \\
\hline month & Obs. Freq. & & & 0.001 \\
\hline Total & & $(39.2 \%)$ & (79.5\%) & \\
\hline \multirow{7}{*}{$\begin{array}{l}\text { Group I: } 97 \\
\text { Group II: } 78\end{array}$} & Standardized & -2.3 & 2.6 & \\
\hline & $\begin{array}{l}\text { residuals } \\
1\end{array}$ & & & \\
\hline & Obs. Freq. & $\begin{array}{l}46 \\
(47.4 \%)\end{array}$ & $\begin{array}{l}8 \\
(10.3 \%)\end{array}$ & \\
\hline & $\begin{array}{l}\text { Standardized } \\
\text { residuals }\end{array}$ & 2.9 & -3.3 & \\
\hline & 2 or more & & & \\
\hline & Obs. Freq. & $\begin{array}{l}13 \\
(13.4 \%)\end{array}$ & $\begin{array}{l}8 \\
(10.3 \%)\end{array}$ & \\
\hline & $\begin{array}{l}\text { Standardized } \\
\text { residuals }\end{array}$ & 0.4 & -0.4 & \\
\hline
\end{tabular}

* Chi-square test.

a Significant at the 0.10 level.

Although the dispersion in group I (Rural) and in group II (Urban) is practically the same (standard deviation of 1.19 and 1.32 inhabitants), the average number of inhabitants per day during the weekend varies by about one person from the mean.

Table 8

Comparison of rural and urban environment distributions relating to "Tariff".

\begin{tabular}{lllll}
\hline & & $\begin{array}{l}\text { Group I } \\
\text { (Rural) }\end{array}$ & $\begin{array}{l}\text { Group II } \\
\text { (Urban) }\end{array}$ & $p$-Value \\
\hline Tariff & Simple tariff & & & $p=0.005$ \\
Total & Obs. Freq. & $121(89.6 \%)$ & $84(76.4 \%)$ & \\
Group I: 135 & Standardized residuals & 0.8 & -0.8 & \\
Group II: 110 & Dual tariff & $14(10.4 \%)$ & $26(23.6 \%)$ & \\
& Obs. Freq. & -1.7 & 1.9 & \\
& Standardized residuals & -1.7 & \\
\hline
\end{tabular}

a Chi-square test.
Table 9

Comparison of rural and urban environment distributions relating to "Public supply network", “Water hole or well”, “Domestic consumption", "Garden irrigation”, and "Terrace washing".

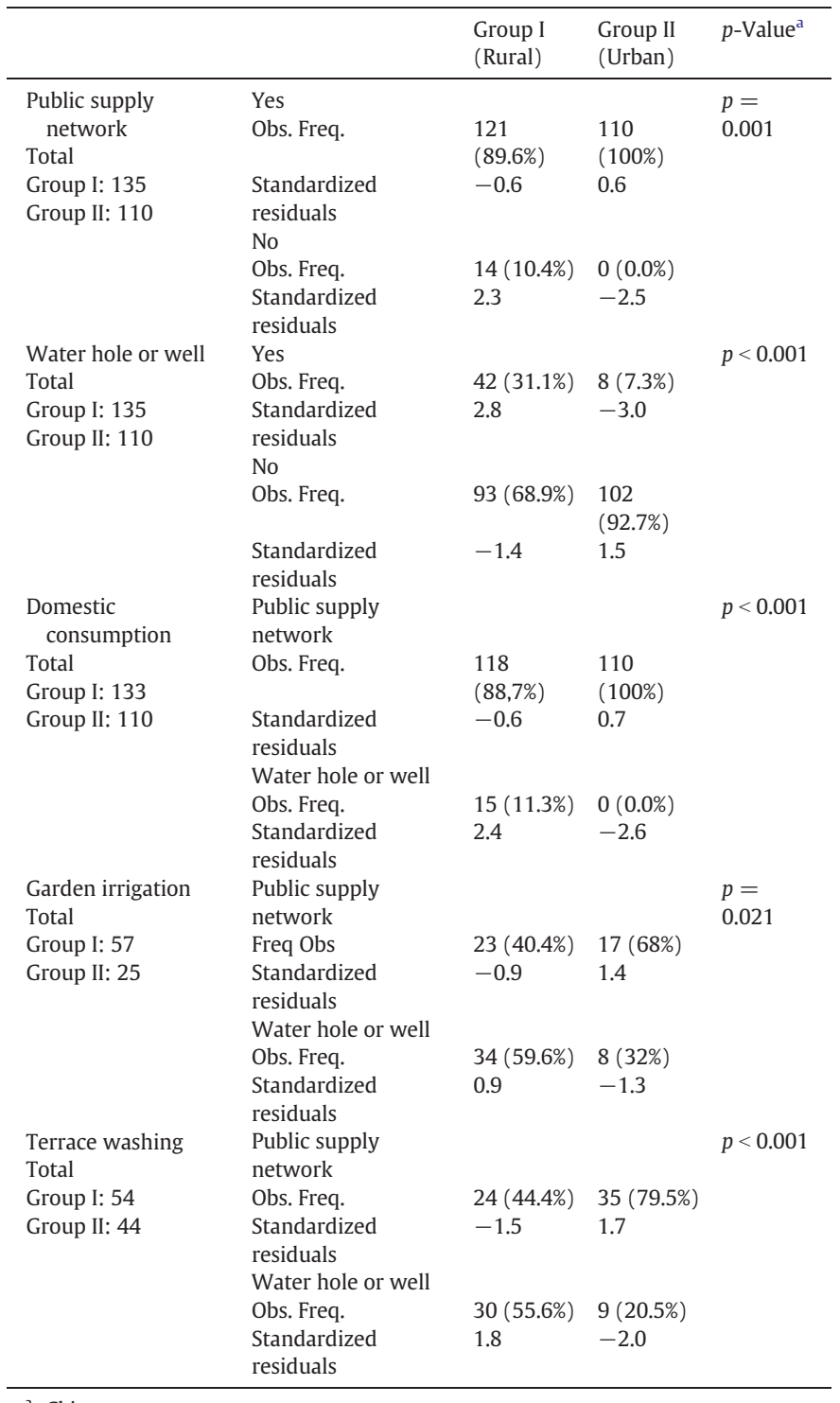

a Chi-square test.

With regard to the education level of family members, it is the urban sampled household which holds higher academic levels than the group of the rural households. In each household, the most frequent number of inhabitants (mode) is 2, with "High school and higher education" and with "Basic education", in urban and rural respectively.

The results indicate that were found statistically significant differences concerning the number of inhabitants in each education level by environment: "No education" ( $p$-value $=0.029)$, "Basic education" ( $p$ value $<0.001$ ), and "High school and higher education" ( $p$-value $<$ 0.001 ). The average number of inhabitants with "No education" ranges from 0 to 2 for Group I (Rural), and 0 to 1 for Group II (Urban). Regarding the number of inhabitants with "No education" in both groups, it should be noted that the majority of the households have an education level (mode $=0$ ) and also that both groups presents an average of about 0 inhabitants ( mean $=0.1$ and mean $=0.03$ ). The standard deviation (0.16) of the urban area is less than half of the urban area (0.39), because the number of inhabitants with "No education" in this group is less variable.

Concerning the number of inhabitants with "Basic education", it is observed that rural environment presents an average of about two 
Table 10

Comparison of rural and urban environment distributions relating to "Manual washing", "Manual washing in wash tub", "Efficiency class washing", "Timetable of washing machine uses", and "Water for manual washing".

\begin{tabular}{|c|c|c|c|c|}
\hline & & $\begin{array}{l}\text { Group I } \\
\text { (Rural) }\end{array}$ & $\begin{array}{l}\text { Group II } \\
\text { (Urban) }\end{array}$ & $p$-Value* \\
\hline Manual washing & Yes & & & $p<$ \\
\hline Total & Obs. Freq. & 59 & 22 & 0.001 \\
\hline Group I: 135 & & $(43.7 \%)$ & $(20.2 \%)$ & \\
\hline \multirow[t]{4}{*}{ Group II: 110} & $\begin{array}{l}\text { Standardized } \\
\text { residuals }\end{array}$ & 2.1 & -2.4 & \\
\hline & No & & & \\
\hline & Obs. Freq. & $\begin{array}{l}76 \\
(56.3 \%)\end{array}$ & $\begin{array}{l}87 \\
(79.8 \%)\end{array}$ & \\
\hline & $\begin{array}{l}\text { Standardized } \\
\text { residuals }\end{array}$ & -1.5 & 1.7 & \\
\hline Washing tank & Yes & & & $p^{a}=$ \\
\hline Total & Obs. Freq. & 36 & 18 & 0.053 \\
\hline Group I: 135 & & $(26.7 \%)$ & $(16.4 \%)$ & \\
\hline \multirow[t]{3}{*}{ Group II: 110} & $\begin{array}{l}\text { Standardized } \\
\text { residuals } \\
\text { No }\end{array}$ & 1.1 & -1.3 & \\
\hline & Obs. Freq. & $\begin{array}{l}99 \\
(73.3 \%)\end{array}$ & $\begin{array}{l}92 \\
(83.6 \%)\end{array}$ & \\
\hline & $\begin{array}{l}\text { Standardized } \\
\text { residuals }\end{array}$ & -0.6 & 0.7 & \\
\hline \multirow{2}{*}{$\begin{array}{l}\text { Efficiency class washing } \\
\text { machine }\end{array}$} & $\mathrm{A}+++$ & & & $p<$ \\
\hline & Obs. Freq. & $6(5.0 \%)$ & 16 & 0.001 \\
\hline Total & & & $(16.0 \%)$ & \\
\hline \multirow{12}{*}{$\begin{array}{l}\text { Group I: } 135 \\
\text { Group II: } 110\end{array}$} & Standardized & -1.7 & 1.9 & \\
\hline & residuals & & & \\
\hline & $\mathrm{A}++$ & & & \\
\hline & Obs. Freq. & $\begin{array}{l}12 \\
(10.1 \%)\end{array}$ & $\begin{array}{l}40 \\
(40.0 \%)\end{array}$ & \\
\hline & $\begin{array}{l}\text { Standardized } \\
\text { residuals }\end{array}$ & -3.1 & 3.3 & \\
\hline & $\mathrm{A}+$ & & & \\
\hline & Obs. Freq. & $\begin{array}{l}64 \\
(53.8 \%)\end{array}$ & $\begin{array}{l}31 \\
(31.0 \%)\end{array}$ & \\
\hline & $\begin{array}{l}\text { Standardized } \\
\text { residuals } \\
\text { A }\end{array}$ & 1.7 & -1.9 & \\
\hline & Obs. Freq. & $\begin{array}{l}31 \\
(26.1 \%)\end{array}$ & $\begin{array}{l}10 \\
(10.0 \%)\end{array}$ & \\
\hline & $\begin{array}{l}\text { Standardized } \\
\text { residuals } \\
\text { B }\end{array}$ & 1.8 & -2.0 & \\
\hline & Obs. Freq. & $6(5.0 \%)$ & $3(3.0 \%)$ & \\
\hline & $\begin{array}{l}\text { Standardized } \\
\text { residuals }\end{array}$ & 0.5 & -0.5 & \\
\hline $\begin{array}{l}\text { Timetable of washing } \\
\text { machine uses }\end{array}$ & $\begin{array}{l}\text { 8:00 am-11:59 } \\
\text { am }\end{array}$ & & & $\begin{array}{l}p= \\
0.002\end{array}$ \\
\hline Total & Obs. Freq. & $7(5.7 \%)$ & $8(7.7 \%)$ & \\
\hline \multirow{11}{*}{$\begin{array}{l}\text { Group I: } 122 \\
\text { Group II: } 96\end{array}$} & Standardized & -0.4 & 0.4 & \\
\hline & residuals & & & \\
\hline & $\begin{array}{l}\text { 12:00 am-07:59 } \\
\text { pm }\end{array}$ & & & \\
\hline & Obs. Freq. & $6(4.9 \%)$ & $8(6.4 \%)$ & \\
\hline & $\begin{array}{l}\text { Standardized } \\
\text { residuals }\end{array}$ & -0.6 & 0.6 & \\
\hline & $\begin{array}{l}\text { 08:00 pm-7:59 } \\
\text { am }\end{array}$ & & & \\
\hline & Obs. Freq. & $\begin{array}{l}15 \\
(12.3 \%)\end{array}$ & $\begin{array}{l}32 \\
(30.8 \%)\end{array}$ & \\
\hline & $\begin{array}{l}\text { Standardized } \\
\text { residuals }\end{array}$ & -2.1 & 2.2 & \\
\hline & Random & & & \\
\hline & Obs. Freq. & $\begin{array}{l}94 \\
(77.0 \%)\end{array}$ & $\begin{array}{l}56 \\
(53.8 \%)\end{array}$ & \\
\hline & $\begin{array}{l}\text { Standardized } \\
\text { residuals }\end{array}$ & 1.4 & -1.6 & \\
\hline Water for manual washing & Cold water & & & $p<$ \\
\hline Total & Obs. Freq. & 49 & 5 & 0.001 \\
\hline Group I: 159 & & $(83.1 \%)$ & $(23.8 \%)$ & \\
\hline \multirow[t]{3}{*}{ Group II: 21} & $\begin{array}{l}\text { Standardized } \\
\text { residuals }\end{array}$ & 1.5 & -2.4 & \\
\hline & Cold and warm w & & & \\
\hline & Obs. Freq. & 10 & 16 & \\
\hline
\end{tabular}

Table 10 (continued)

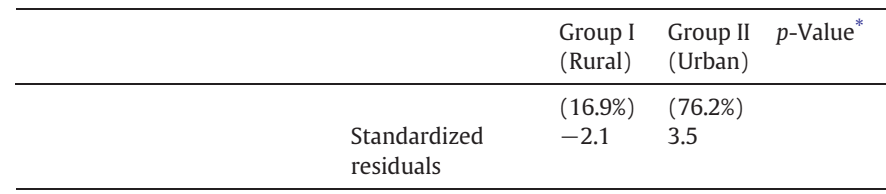

* Chi-square test.

a Significant at the 0.10 level.

inhabitants (1.8), a higher value than the one obtained for the urban environment, which presents an average of about one inhabitant (0.7). The data variability in both environments it's almost the same: (std.

Table 11

Comparison of rural and urban environment distributions relating to "Dishwasher", "Manual dishwashing", "Number of manual dishwashings", and "Water for manual dishwashing".

\begin{tabular}{|c|c|c|c|c|}
\hline & & $\begin{array}{l}\text { Group I } \\
\text { (Rural) }\end{array}$ & $\begin{array}{l}\text { Group II } \\
\text { (Urban) }\end{array}$ & $p$-Value ${ }^{*}$ \\
\hline Dishwasher & Yes & & & $p=$ \\
\hline Total & Obs. Freq. & 59 & 70 & 0.002 \\
\hline Group I: 135 & & $(43.7 \%)$ & $(63.6 \%)$ & \\
\hline \multirow[t]{4}{*}{ Group II: 110} & $\begin{array}{l}\text { Standardized } \\
\text { residuals }\end{array}$ & -1.4 & 1.6 & \\
\hline & No & & & \\
\hline & Obs. Freq. & $\begin{array}{l}76 \\
(56.3 \%)\end{array}$ & $\begin{array}{l}40 \\
(36.4 \%)\end{array}$ & \\
\hline & $\begin{array}{l}\text { Standardized } \\
\text { residuals }\end{array}$ & 1.5 & -1.7 & \\
\hline Manual dishwashing & Yes & & & $p^{\mathrm{a}}=$ \\
\hline Total & Obs. Freq. & 122 & 90 & 0.051 \\
\hline Group I: 135 & & $(90.4 \%)$ & $(81.8 \%)$ & \\
\hline \multirow[t]{3}{*}{ Group II: 110} & $\begin{array}{l}\text { Standardized } \\
\text { residuals } \\
\text { No }\end{array}$ & 0.5 & -0.5 & \\
\hline & Obs. Freq. & $13(9.6 \%)$ & $\begin{array}{l}20 \\
(18.2 \%)\end{array}$ & \\
\hline & $\begin{array}{l}\text { Standardized } \\
\text { residuals }\end{array}$ & -1.2 & 1.3 & \\
\hline \multirow{2}{*}{$\begin{array}{l}\text { Number of manual } \\
\text { dishwashings }\end{array}$} & 0 & & & $p=$ \\
\hline & Obs. Freq. & $2(1.7 \%)$ & $0(0.0 \%)$ & 0.006 \\
\hline \multirow{11}{*}{$\begin{array}{l}\text { Total } \\
\text { Group I: } 121 \\
\text { Group II: } 89\end{array}$} & Standardized & 0.8 & -0.9 & \\
\hline & residuals & & & \\
\hline & 1 to 3 & & & \\
\hline & Obs. Freq. & $\begin{array}{l}14 \\
(11,6 \%)\end{array}$ & $\begin{array}{l}12 \\
(13.5 \%)\end{array}$ & \\
\hline & $\begin{array}{l}\text { Standardized } \\
\text { residuals } \\
4 \text { to } 6\end{array}$ & -0.3 & 0.3 & \\
\hline & Obs. Freq. & $9(7.4 \%)$ & $\begin{array}{l}16 \\
(18.0 \%)\end{array}$ & \\
\hline & $\begin{array}{l}\text { Standardized } \\
\text { residuals } \\
7 \text { to } 10\end{array}$ & -1.4 & 1.7 & \\
\hline & Obs. Freq. & $\begin{array}{l}65 \\
(53.7 \%)\end{array}$ & $\begin{array}{l}28 \\
(31.5 \%)\end{array}$ & \\
\hline & $\begin{array}{l}\text { Standardized } \\
\text { residuals } \\
\text { More than } 10\end{array}$ & 1.6 & -1.8 & \\
\hline & Obs. Freq. & $\begin{array}{l}31 \\
(25.6 \%)\end{array}$ & $\begin{array}{l}33 \\
(37.1 \%)\end{array}$ & \\
\hline & $\begin{array}{l}\text { Standardized } \\
\text { residuals }\end{array}$ & -1.0 & 1.1 & \\
\hline \multirow{7}{*}{$\begin{array}{l}\text { Water for manual } \\
\text { dishwashing } \\
\text { Total } \\
\text { Group I: } 120 \\
\text { Group II: } 89\end{array}$} & Warm water & & & $p=$ \\
\hline & Obs. Freq. & 50 & 24 & 0.028 \\
\hline & & (41.7\%) & (27.0\%) & \\
\hline & $\begin{array}{l}\text { Standardized } \\
\text { residuals }\end{array}$ & 1.2 & -1.3 & \\
\hline & $\begin{array}{l}\text { Cold and warm } \\
\text { water }\end{array}$ & & & \\
\hline & Obs. Freq. & $\begin{array}{l}70 \\
(58.3 \%)\end{array}$ & $\begin{array}{l}65 \\
(73.0 \%)\end{array}$ & \\
\hline & $\begin{array}{l}\text { Standardized } \\
\text { residuals }\end{array}$ & -0.9 & 1.0 & \\
\hline
\end{tabular}

* Chi-square test.

a Significant at the 0.10 level. 
dev. $=1.09$ and std. dev. $=1.03$ ). In both environments it was observed the existence of households with 6 inhabitants (maximum) with "Basic education".

The number of inhabitants with "High school and higher education" varies between 0 and 4 for Group I (Rural) and 0 to 5 for Group II (urban). Note that in the rural environment the most frequent number is 0 people with these school qualifications, while in Group II it is 2 people (mode $=0$ and mode $=2$ ). Also, the mean of the number of inhabitants with "High school and higher education" in the urban area (about 2 persons) is twice that of rural area.

The number of active professional inhabitants in each household is greater in urban areas than in rural ones. In average, about 2 inhabitants and only 1 inhabitant are professionally active per household in the cities and in the countryside, respectively.

In the case of rural environment, the dispersion is higher, with a standard deviation of 1.18 people, compared to urban environment, with a standard deviation of $0.81(p=0.001)$.

The number of inhabitants without professional activity varies between 0 and 4 in the rural areas, and 0 and 3 in the urban ones. It should be noted that in rural areas the most frequent situation is 2 inhabitants without professional activity, while in urban areas no household presents this situation (mode $=2$ and mode $=0$ ). In the case of rural areas, the dispersion is again higher (std. dev. $=1.18$ ) than in urban areas, with a standard deviation of $0.81(p<0.001)$.

The number of meals per week ranges from 2 to 24 for the rural group, and 0 to 45 for the urban group. It should be noted that in the rural group most frequently has 21 meals per week, while the urban group has only 14 meals (mode $=21$ and mode $=14$ ). The surveyed rural households present an average of 16.7 meals per week (std. dev. $=5.68$ ), a higher value when compared with the urban ones, with a mean of 11.2 (std. dev. $=6.45$ ), but the data variability is higher in urban areas. It can be concluded that the "Number of meals per week" is statistically significantly different in the two environments $(p<$ 0.001).

\subsection{Building information}

Considering the 135 households that answered the survey in a rural region, $69.6 \%$ are "Single family dwelling (SFD), isolated" and only $14.5 \%$ of the 110 households in an urban region have this type of family dwelling (Table 6). In the urban regions, $70.0 \%$ of the households are "Multidwelling units (MDU)", in contrast to the rural environment, where only 3.7\% of families are MDU. SFD and MDU categories are more frequent in rural environments, while MDUs tend to be more frequent in the urban areas, as expected.

The analysis of the discrepancies between the observed frequency and the expected frequency indicates that MDU and SFU categories are the most influential in the non-homogeneity of proportions, the first category containing fewer households in rural environments than expected, and the second category including a higher number than expected $(\chi 2(2)=124.081, p$-value $<0.001)$.

Both groups under study assumed "Until 1990" as modal category for the year of dwelling constructions (64.7\% in rural areas and $53.2 \%$ in urban ones), and only seven and fourteen households in rural and urban areas were built after 2006, respectively (Table 6). However, households in urban environments have newer dwellings, with $48 \%$ of the dwellings built "Between 1990 and 2006", and 13.6\% built "Between 2006 and 2013" $(\chi 2(2)=17.124$, $p$-value $<0.001)$. In Portugal, according to ICESD, only $7.5 \%$ of the dwellings were built before 1946 and $10.8 \%$ after 2000 . In a regional analysis, it can be seen that in this country the period with higher values of construction was 1981-1999 (37.6\%), followed by the period 1961-1980 (34.9\%).

The data shows that houses with areas "Between $100 \mathrm{~m}^{2}$ and $200 \mathrm{~m}^{2}$ " appear as a modal category in both study groups (39.3\% and $49 \%$, in rural and urban respectively). However, categories "Between

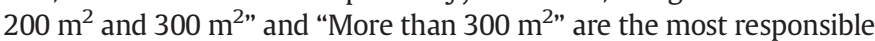

for non-equality frequency counts distributions across the two studied environments $(\chi 2(3)=7.071, p$-value $=0.07)$. The houses with a larger area, although in smaller number in both environments, are mainly in the countryside. The average area of accommodation in Portugal is around $107 \mathrm{~m}^{2}$ /household, (ICESD, 2010), what follows within the values obtained in here.

The significance level for this study was set to $5 \%$, and it is used to refer to a pre-chosen probability of error. However, based on literature that considers the importance of certain variables in the characterization of water and energy consumption in rural and urban households, it is considered an error of $\alpha=10 \%$, as happened when the test of chi-square of homogeneity was applied to the house area variable from two different environments.

Regarding building typology, once again it is observed a contrast between the two environments: $96.3 \%$ are houses in a rural environment and $70.9 \%$ are apartments in an urban environment. It is statistically significant to conclude that the distribution of building typology for rural and urban environments is not the same $(\chi 2(1)=122.210, p$-value $<$ 0.001 ).

The data analysis of the two categories "yes" and "no" about the existence of gardens in the housing in both environments indicates that they are equally responsible for the statistically significant differences in the distributions, but the proportion of houses with a garden is higher than the expected frequency and, on the contrary, the observed frequency of houses without garden is less than the expected frequency. Thus, this confirms that the majority of the surveyed rural population has a garden (57\%) and the majority of the surveyed urban population does not have a garden $(73.6 \%)(\chi 2(1)=23.232, p$-value $<0.001)$.

As expected, concerning building information about exterior areas terrace and backyard, most of rural households have higher frequencies of these type of outdoor spaces: terrace $63.7 \%$ (rural) versus $51.8 \%$ (urban), and backyard 50.4\% (rural) versus 11.8\% (urban) (Table 7). In particular, in rural regions the biggest frequency of terrace area is "Between 10 and $20 \mathrm{~m}^{2}$ " (46\%), and in urban regions is "Less than $10 \mathrm{~m}^{2}$ " (49.1\%).

Were found statistically significant differences, at $\alpha=0.10$ level, in frequency counts distribution of rural and urban environments, about to have "Terrace" $(\chi 2(1)=3.524, p$-value $=0.060)$, and about "Terrace area" $(\chi 2(2)=4.940, p$-value $=0.085)$. It may be also concluded that the distributions of housing having or not having "Backyard" $(\chi 2(1)=$ $40.706, p$-value $<0.001$ ) don't have identical behavior in the two studied groups.

As expected, due to the nature of the dwelling, only $20.6 \%$ of respondents of the surveyed households in an urban environment usually wash the cars per month at home; however, $60.8 \%$ of respondents in rural regions wash their cars at home (47.4\% do one car washing per month and $13.4 \%$ two or more car washings per month). The "Number of car washings per month" distributions are not identical in the two environments $(\chi 2(2)=32.006, p$-value $<0.001)$.

\subsection{Energy consumption}

A key goal of the survey was to study the rural and urban households 'consumption patterns concerning water and energy (natural gas and electricity)'.

In the case of households' annual natural gas consumption, 95.5\% of the cases in the rural area does not use this energy source, using other sources of energy such as firewood, coal, pellets, gas oil, LPG and others. In urban areas, this energy source is not used in $49 \%$ of the cases, possibly due to the fact that some homes are not yet served with natural gas. In urban areas, the highest percentage $(28.1 \%$ ) of households spend between 0.019 and 0.041 toe natural gas per year (Fig. 3).

In this study, all households used two types of annual electricity consumption tariff: simple and dual tariff. The main difference between them is the price: simple tariff has only one price for all the daily period and dual tariff has two prices for two different daily periods. 


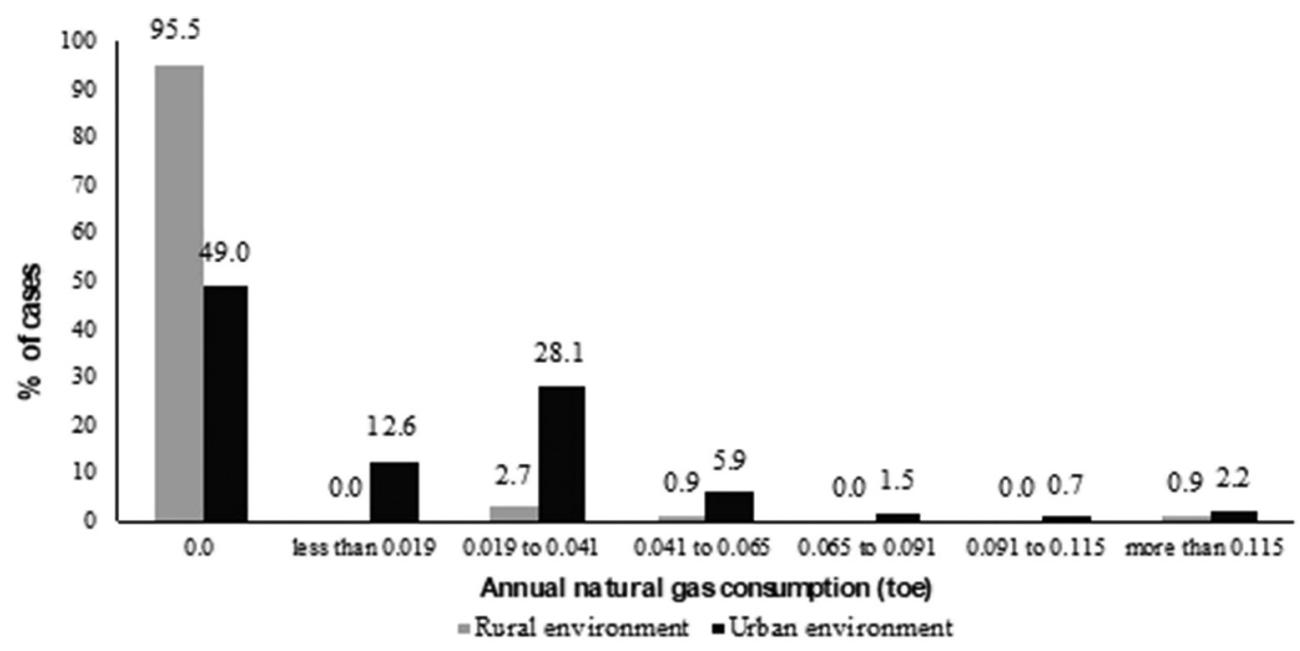

Fig. 3. Description of households' annual natural gas consumption.

The majority of families opted for a simple tariff: $89.6 \%$ in rural areas and $76.4 \%$ in urban areas (Table 8 ).

Fig. 4 displays the percentage of respondents using the annual electricity simple tariff by household environment. It is verified that the majority of them spend $<0.016$ toe of electricity (54.8\% rural and $37.3 \%$ urban).

Fig. 5 illustrates the percentage of respondents using the annual electricity consumption with dual tariff by household environment. In rural areas, the highest percentage (3.7\%) of households spend between 0.018 and 0.041 toe of electricity; in contrast, in urban areas (13.6\%) spend $<0.018$ toe of electricity.

There is a tendency for the "Dual" tariff to be selected by urban households and the "Simple" tariff by rural households (by comparing the signal of the expected frequencies). The analysis of observed and expected frequency discrepancy indicates that the "Dual" tariff is the most influential category in the homogeneity of proportions by including fewer cases than predicted $(\chi 2(1)=7.808, p$-value $=0.050)$ (Table 8$)$.

\subsection{Water consumption}

Fig. 6 shows the annual water consumptions from a public supply network across two observed environments. The $10.4 \%$ of rural dwellings that did not present any type of water consumption from the public network only use water from a well or a hole, while in urban areas this situation happens in only $0.9 \%$ cases. More than half of the rural households (53.3\%) consumes lower than $6 \mathrm{~m}^{3}$ of water from a public supply network; in contrast, the majority of urban households (70\%) consumes between 6 and $16 \mathrm{~m}^{3}$.

In order to identify the domestic water source and water usage characteristics for domestic consumption in both environments several questions were made, particularly to find out if outdoor uses included water for garden irrigation and terrace washing (Table 9).

Nearly $89.6 \%$ of the surveyed households used the public supply network and all urban surveyed households (100\%) used the same water source. Public supply network frequency counts are not identically distributed across the studied environments $(\chi 2(1)=12.099, p$-value $=$ $0.001)$. Only a small percentage of all respondents have water holes or wells (31.1\% and $7.3 \%$, in rural and urban areas, respectively), and, besides that, it was determined that the distribution of rural percentages differed significantly from the urban ones $(\chi 2(1)=21.205$, $p$-value $<$ 0.001).

Only $31.1 \%$ (rural) and 7.3\% (urban) - corresponding to 8 households - use a hole or a well as their water sources for consumption. Besides that, no household in urban environment uses hole or well water for domestic use and only 15 households (11.3\%) use hole and well water for domestic use $(\chi 2(1)=13.222, p$-value $<0.001)$. Domestic consumption is entirely from the public supply network (100\%) and also in the majority of rural households (88.7\%).

Concerning the use of water from holes and wells, approximately $59.6 \%$ and $55.6 \%$ of the rural sampled households answered that they use this source of water for garden irrigation and terrace washing, but the majority of the urban households responded that they used water from the public supply network for garden irrigation (68\%) and terrace washing (79.5\%) (Table 9). Only 9 urban households used hole and well water for terrace washing and 8 for garden irrigation. This survey suggests that the use of the two types of source water (water hole or well and public supply network) in "Garden irrigation" $(\chi 2(1)=5.317, p$ value $=0.021)$, and in "Terrace washing" $(\chi 2(1)=12.468, p$-value $<$ 0.001 ) is not the same in both regions.

Regarding water consumption related to personal hygiene (taking a shower or a bath), this study reflects that the number of showers the interviewed families have in a week is higher than the number of baths, in both environments.

The number of weekly showers in the households ranges from 1 to 50 (rural region) and 3 and 50 (urban region). It should be noted that in the rural group the most frequent number is 4 showers per week, while in the urban group it is 14 showers (mode $=4$ and mode $=$ 14) (Table 3). On average, 13.96 showers and 0.3 baths per week are taken by the rural families. The behavior of "Number of showers" per week is very variable, about 10 showers (std. dev. $=9.69$ ) around the mean, but the "Number of baths" only varies 1 bath (std. dev. =1.21). In comparison, the urban families present a higher average of 15.9 showers $(p=0.045)$ and 1.7 baths $(p=0.01)$, and standard deviations of 9 showers and about 6 baths per week, which represent an enormous data variability.

\subsection{Washing}

Regarding water consumption for clothes washing (machine and manually) it is verified that the following factors distributions are statistically significant different in rural and urban family environments: types of washing (washing machine usage, manual washing, manual washing in a washing tank), efficiency class washing machine, timetables and durations of washing machine uses, water for manual washing and duration of manual washing (Table 10).

Approximately $43.7 \%$ (rural) and $20.2 \%$ (urban) of the sampled households responded that they also wash clothes manually and, among these, a small portion of the families have a washing tank (rural 26.7\% and urban 16.4\%). Interestingly, for this type of task, 83.1\% use cold water in rural environment and $76.2 \%$ use cold and warm water in urban environment (Table 10). 


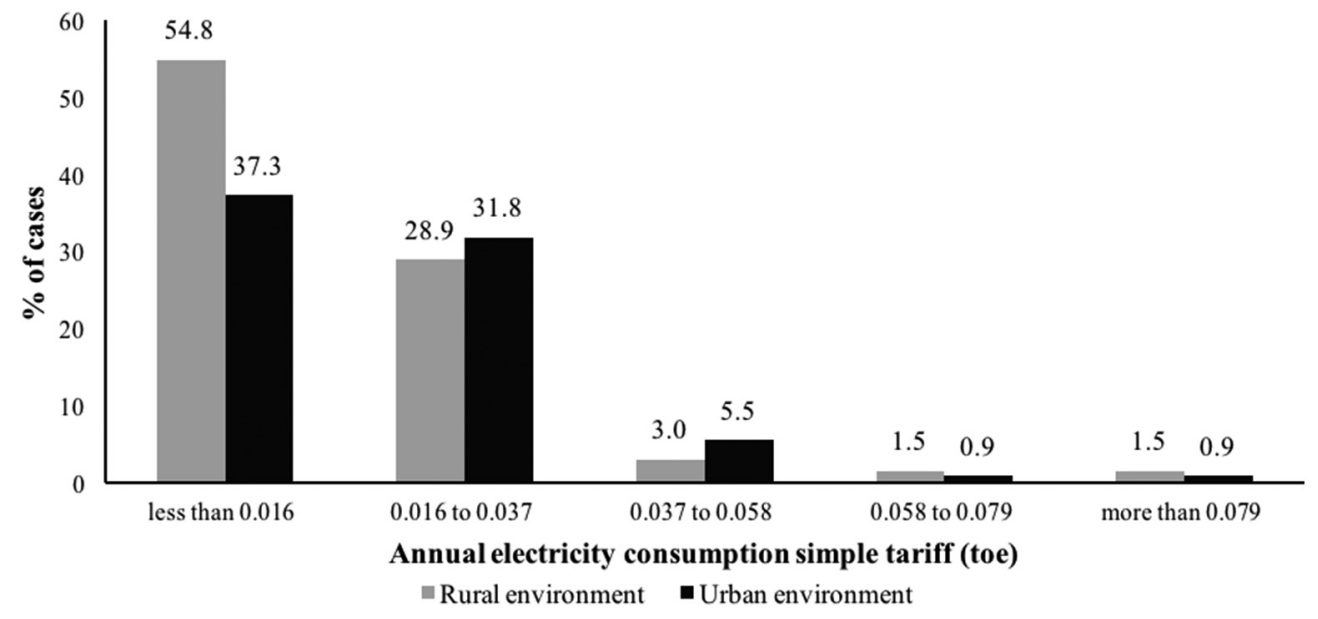

Fig. 4. Description of households' annual electricity consumption with simple tariff.

In both environments, there isn't a typical timetable for washing machine uses: $77 \%$ (rural) and about 54\% (urban) responded that they used a random timetable. However, the timetable from 08:00 pm to 7:59 am for washing machine uses is the most responsible category for the nonhomogeneity of the proportion of families in the two environments in the different timetables of washing machine uses: (more than twice the percentage of the families in urban areas $(30.8 \%)$ in comparison to rural environment (12.3\%)).

The efficiency class washing machine mostly used is class $\mathrm{A}^{++}$in urban households (40\%) and $\mathrm{A}^{+}$in rural households (53.8\%). Only a small number of houses use the $A$ and $B$ class washing machine: $5 \%$ (A) and 5.7\% (B), and 3\% (A) and 7.7\% (B) in rural and urban environments, respectively. Class $\mathrm{A}^{++}$is the most responsible category for the non-homogeneity of the proportion of families in the two environments concerning the different efficiency classes' washing machine.

The duration of the washing machine uses varies between $15 \mathrm{~min}$ and $240 \mathrm{~min}$ for rural households and $25 \mathrm{~min}$ and $180 \mathrm{~min}$ for urban households. It should be noted that in rural areas the most frequent duration of usage is $90 \mathrm{~min}$ while in the urban areas it is $60 \mathrm{~min}$ (mode $=$ 90 and mode $=60$ ). Particularly, an average of $86.8 \mathrm{~min}$ is observed in rural environment, and a standard deviation of $32.07 \mathrm{~min}$, which represents a high variability of durations. In urban environment it was found an average of $78.1 \mathrm{~min}$ (SD $37.45 \mathrm{~min}$ ), a lower average but an even greater variability of durations of washing machine uses, when comparing with rural areas (Table 3 ).
After analyzing the "Duration of manual washing", it is observed that the rural group presents an average of $22.9 \mathrm{~min}$, almost twice the value mean 12.1 min of the urban group. The same happens for the dispersion of this category: a standard deviation of $11.43 \mathrm{~min}$, almost twice the value standard deviation of $5.91 \mathrm{~min}$ (a greater variability of durations in rural area). It is important to emphasize that the minimum value observed was the same in both environments ( $5 \mathrm{~min}$ ), but the maximum value observed was $60 \mathrm{~min}$ in rural area, which is the double of the maximum (30 min) observed in urban area (Table 3).

\subsection{Dishwashing}

Several variables distributions related to the dishwashing process involving water and energy consumption were analyzed and the results are presented only for those that were significantly different in both rural and urban environments (Tables 3 and 11).

In the two environments there is a greater number of families that don't use a dishwasher in rural area (56.3\%) and, in contrast, a greater number of families use a dishwasher $(63.6 \%)$ in urban area $(\chi 2(1)=$ $9.660, p$-value $=0.002$ ). The majority of families also do manual dishwashing (90.4\% rural and $81.8 \%$ urban), but the percentage of urban households that don't do manual dishwashing (18.2\%) is higher than that in rural areas (only 9.6\%) $(\chi 2(1)=3.804, p$-value $=0.051$ ).

Concerning the number of manual dishwashing per week, "7 to 10 " is the modal category for rural environment (53.7\%), and "More than

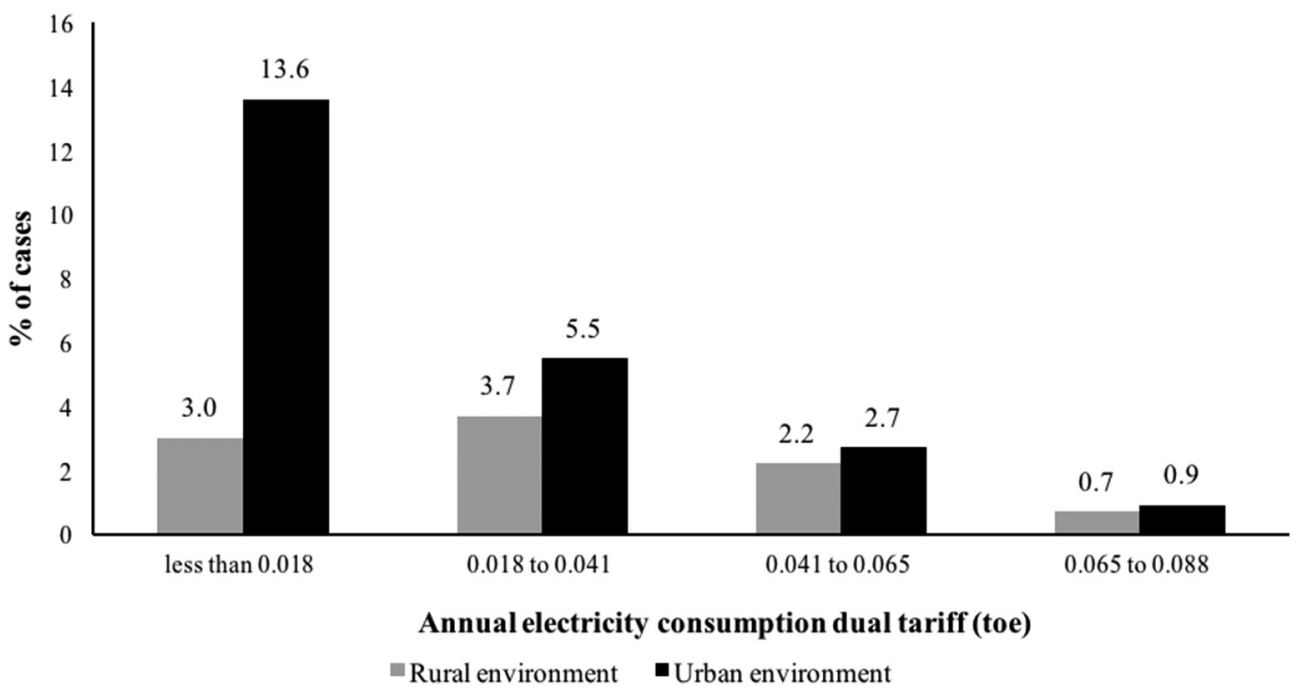

Fig. 5. Description of households' annual electricity consumption with dual tariff. 


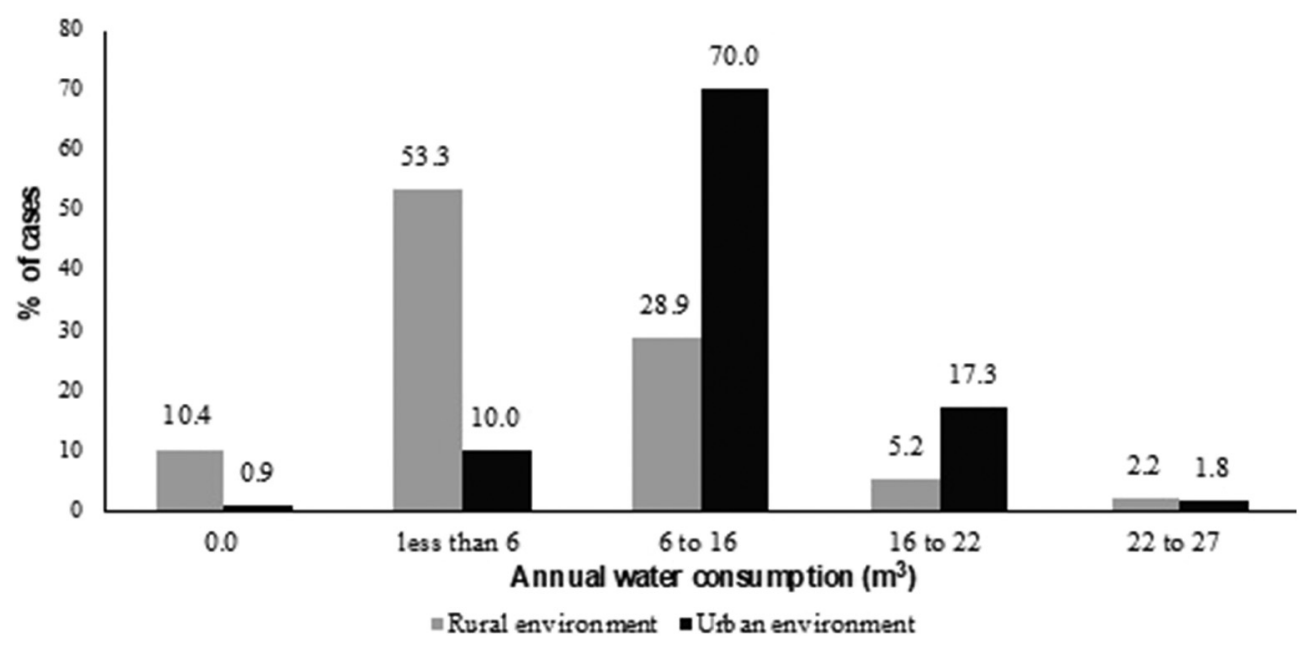

Fig. 6. Description of households' annual water consumption from a public supply network

10 " as modal category (37.1\%) for urban environment. From the analysis of the residuals that arise in each of the categories, it is observed that the one that most influences the non-homogeneity of the proportion is " 4 to 7" category (with a higher number of households in the urban group), surpassing what would be expected, and "7 to 10" manual dishwashing per week (with a higher number of households in the rural group), also exceeding the expected frequency $(\chi 2(4)=14.354$, $p$-value $=0.006)$.

Considering the "Water for manual dishwashing" category, the majority of households use "Cold and warm water" (rural 58.3\% and urban $73 \%$ ). The analysis of the discrepancies between observed frequency and expected frequency indicates that category "Warm water" is the most responsible for the non-homogeneity of the distributions of proportions of "Water for manual dishwashing", containing more households of rural environment than expected $(\chi 2(1)=4.828, p$-value $=0.028)$.

The temperature of dishwasher usage varies between $30^{\circ} \mathrm{C}$ and 80 ${ }^{\circ} \mathrm{C}$ in rural areas and $10{ }^{\circ} \mathrm{C}$ and $100{ }^{\circ} \mathrm{C}$ in urban areas. It should be noted that the predominant temperature of dishwasher usage in rural households is $40^{\circ} \mathrm{C}$, while in urban households it is greater: $60{ }^{\circ} \mathrm{C}$. The average temperature of dishwasher in urban environment $\left(45.4^{\circ} \mathrm{C}\right)$ is higher than in rural environment $\left(53.5^{\circ} \mathrm{C}\right)$ and the temperatures also present a higher variability in urban environment (SD values of 15.6 ${ }^{\circ} \mathrm{C}$ in urban environment and $12.6{ }^{\circ} \mathrm{C}$ in rural environment) $(p=0.001)$.

Both the mean and the standard deviation of dishwasher usage duration are higher in urban environment (mean $=82.5 \mathrm{~min}$, std. dev. $=41.62 \mathrm{~min}$ ) than in rural environment (mean $=65.5 \mathrm{~min}$, std. dev. $=38.01 \mathrm{~min}$ ). The duration of manual dishwashing varies in the two environments: from 30 to $180 \mathrm{~min}$ (rural) and from 29 to $185 \mathrm{~min}$ (urban). It was observed that in both regions the most frequent duration is 60 min of manual dishwashing. On average, the households spend $16.3 \mathrm{~min}$ in manual dishwashing, with a standard deviation of $5.31 \mathrm{~min}$ in rural environment in comparison with urban durations, whose average is $13.4 \mathrm{~min}$, with slightly higher standard deviation $(6.37 \mathrm{~min})(p<0.001)$.

\section{Conclusions}

In this research work, several differences between rural and urban environments were found. It is expected that the identified variables may influence the water and energy consumptions and so, an interconnected relation between water and energy can then be established.

The research started to consider $>80$ variables based on the bibliography, which decreased to 42 after the statistical treatment of the survey data.

In what concerns to occupant information, namely the socioeconomic variables (housekeeper; professional activity; income; education level; employment) the results were significantly different. The number of positive answers was higher in urban than in rural households. In this category, as expected, it was found that in rural areas, the number of inhabitants in home per day was higher in rural than in urban areas. All these signs may have origin in the fact that rural population is usually older and so some of these inhabitants are already retired. The "age" variable did not show significant differences between the environments, however, the number of inhabitants with age higher than 67 years was bigger in the rural case ( $n=99$ to 20 answers in urban environment).

Relatively in the category of "Building information" for the variables type of housing, building typology, age of building, area, garden, terrace (presence and area), backyard and number of car washings per month, different results were obtained for the two environments. Some of them were expected, as the presence of garden, terrace and backyard is more in rural areas compared to urban areas.

In what concerns to "Energy consumption", it was noted that urban environments had more consumption of energy than the rural ones. However, in urban environments two types of resource energy are used: natural gas and electricity. In rural areas, electrical energy is predominantly used, given that most of the buildings are not served with natural gas installation. In rural areas dual tariff is not usual.

Annual water consumption is higher in urban areas than in rural environments. Although the number of holes and wells is higher in rural areas, almost all the domestic consumption is from the public water supply network, what reflects a high percentage if attendance with public facilities in this areas, as on the urban environments. Relatively to the water use, it was observed that in urban areas water is used mostly for hygiene and domestic consumption. Since the number of gardens and terraces is lower in urban areas, the consumption of water for these purposes was also expected to be lower.

Washing category reveals that in rural environments people do more manual washing in the washing tank. In urban environments there is greater concern with the energy class used which may be related to the education level of the urban population itself. This has implications on the duration of washing machine uses.

Finally, and in what concerns to "Dishwashing" category, urban households are generally served with a dishwasher, in contrast with rural households where manual dishwashing is bigger.

This research gives an important contribution to identify the factors responsible for the differences between rural and urban areas in what concerns to water and energy consumption.

\section{Acknowledgement}

This work was partially funded by POCI-0-0145-FEDER-016730 Project (PTDC/AAG-REC/4700/2014) with the designation ENERWAT: 
Water to energy: characterization, modelling and measures for the reduction of urban and rural household consumption, financed by the Foundation for Science and Technology and co-financed by the European Regional Development Fund (FEDER) through the COMPETE 2020 - Programme Operational Competitiveness and Internationalization (POCI).

This work was partially supported by the FCT (Portuguese Foundation for Science and Technology) through the project PEst-OE/ECI/ UI4082/2013 (C-MADE).

\section{Appendix A. Supplementary data}

Supplementary data to this article can be found online at https://doi. org/10.1016/j.scitotenv.2018.06.062.

\section{References}

Arpke, A., Hutzler, N., 2006. Domestic water use in the United States - a life cycle approach. J. Ind. Ecol. 10:169-184. https://doi.org/10.1162/108819806775545312. http://onlinelibrary.wiley.com/doi/10.1162/108819806775545312/abstract.

Australian Bureau of Statistics, ABS, 2017. http://www.abs.gov.au.

Basu, M., Hoshino, S., Hashimoto, S., DasGupta, R., 2017. Determinants of water consumption: a cross-sectional household study in drought-prone rural India. Int. J. Disaster Risk Reduct. 24:373-382. https://doi.org/10.1016/j.ijdrr.2017.06.026.

Binks, A.N., Kenway, S.J., Lant, P.A., Head, B.W., 2016. Understanding Australian household water-related energy use and identifying physical and human characteristics of major end uses. J. Clean. Prod. 135:892-906. https://doi.org/10.1016/j. jclepro.2016.06.091.

Cheng, C.L., 2002. Study of the interrelationship between water use and energy conservation for a building. Energ. Buildings 34:261-266. https://doi.org/10.1016/S0378-7788 (01)00097-4. http://www.sciencedirect.com/science/article/pii/S0378778801000974.

Conover, W.J., 1998. Practical Nonparametric Statistical Methods. Third edition. John Wiley \& Sons.
Fan, L., Gai, L., Tong, Y., Li, R., 2017. Urban water consumption and its influencing factors in China: evidence from 286 cities. J. Clean. Prod. 166:124-133. https://doi.org/10.1016/ j.jclepro.2017.08.044.

Haziq, M.A., Panezai, S., 2017. Na empirical analysis of domestic water sources, consumption and associated factors in Kandahar City, Afghanistan. Resour. Environ. 7 (2): 49-61. https://doi.org/10.5923/j.re.20170702.03.

Higgins, J.H., 2004. Introduction to Modern Nonparametric Statistics. Thomson, Toronto.

Hu, S., Yan, D., Guo, S., Cui, Y., Dong, B., 2017. A survey on energy consumption and energy usage behaviour of households and residential building in urban China. Energ. Buildings 148:366-378. https://doi.org/10.1016/j.enbuild.2017.03.064.

ICESD, 2010. Inquérito ao Consumo de Energia no Sector Doméstico. INE (ISSN 21820139).

Instituto Nacional de Estatística, INE, 2015. http://www.ine.pt.

Jonard, F., Lambotte, M., Ramos, F., Terres, J.M., Bamps, C., 2009. Delimitations of Rural Areas in Europe Using Criteria of Population Density, Remoteness and Land Cover. European Commission Joint Research Centre Institute for Environment and Sustainability (JRC49927; EUR 23757 EN; ISSN 1018-5593).

Keshavarzi, A.R., Sharifzadeh, M., Kamgar Haghighi, A.A., Amin, S., Keshtkar, Sh., Bamdad, A., 2006. Rural domestic water consumption behaviour: a case study in Ramjerd area, Fars province, I.R. Iran. Water Res. 40:1173-1178. https://doi.org/10.1016/j. watres.2006.01.021.

Martin, M., 1992. Defining China's rural population. China Q. (130):392-401 URL:. http:// www.jstor.org/stable/654408.

Martinez-Santos, 2017. Determinants for water consumption from improved sources in rural villages of southern Mali. Appl. Geogr. 85:113-125. https://doi.org/10.1016/j. apgeog.2017.06.006.

Matos, C., Teixeira, Carlos A., Bento, Ricardo, Varajão, João, Bentes, Isabel, 2014. An exploratory study on the influence of socio-demographic characteristics on water end uses inside buildings. Sci. Total Environ. 466-467:467-474. https://doi.org/10.1016/j. scitotenv.2013.07.036.

OCDE, 2005. OCDE Regions at a Glance. OCDE, Paris.

Singh, O., Turkiya, S., 2013. A survey of household domestic water consumption patterns in rural semi-arid village, India. GeoJournal 78:777-790. https://doi.org/10.1007/ s10708-012-9465-7. 